\title{
Poly(fluoroalkyl acrylate)-Bound Ruthenium Carbene Complex: A Fluorous and Recyclable Catalyst for Ring-Closing Olefin Metathesis
}

\author{
Qingwei Yao* and Yiliang Zhang \\ Department of Chemistry and Biochemistry, The Michael Faraday Laboratories, \\ Northern Illinois University, DeKalb, Illinois 60115
}

\section{Supporting Information}

General. Unless otherwise noted, all reactions were performed under an atmosphere of dry Ar with oven-dried glassware and anhydrous solvents. THF and diether ether were distilled from sodium/benzophenone under a nitrogen atmosphere. $\mathrm{CH}_{2} \mathrm{Cl}_{2}$ and $\mathrm{PhCF}_{3}$ (purchased from Aldrich, 99+\%) were dried over $\mathrm{CaH}_{2}$, and distilled prior to use. FC-72 were purchased from Acros Organics (Fluoro-compound FC-72 ${ }^{\circledR}$, b.p. 51-59 ${ }^{\circ} \mathrm{C}$ ) and $3 \mathrm{M}$ Company $\left(3 \mathrm{M}^{\mathrm{TM}}\right.$ Fluorinert ${ }^{\mathrm{TM}}$ Electronic Liquid FC-72, b.p. $\left.50-60{ }^{\circ} \mathrm{C}\right)$, and were used as received for the fluorous extraction experiments and distilled under Ar over molecular sieves for use as a solvent for the fluorous biphasic reaction. NMR spectra were acquired in $\mathrm{CDCl}_{3}$ at $500 \mathrm{MHz}$ for ${ }^{1} \mathrm{H}$ and $125 \mathrm{MHz}$ for ${ }^{13} \mathrm{C}$. Acryloyl chloride was purchased from Aldrich and distilled prior to use. Heptadecafluorodecyl acrylate was purchased from Aldrich and used as received. All other chemicals or reagents were obtained from commercial sources or prepared according to literature procedures.

\section{Preparation and Characterization of New Diene Substrates}

$N$-Allyl- $N$-(3-methyl-3-butenyl)-p-toluenesulfonamide (11)

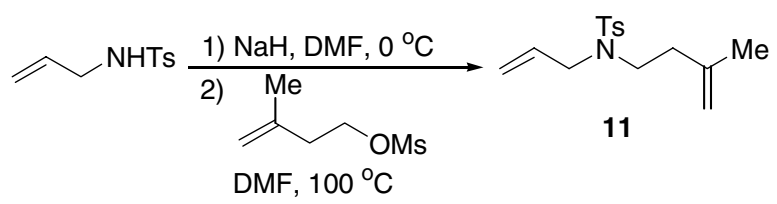

To a solution of $N$-allyl-p-toluenesulfonamide $(4.23 \mathrm{~g}, 20 \mathrm{mmol})$ in DMF $(50 \mathrm{~mL})$ was added $\mathrm{NaH}(1.04 \mathrm{~g}$, $60 \%, 26 \mathrm{mmol}$ ) in one portion at $0{ }^{\circ} \mathrm{C}$. After $\mathrm{H}_{2}$ evolution ceased, a solution of 3-methyl-3-butenyl methanesulfonate $(3.94 \mathrm{~g}, 24 \mathrm{mmol})$ in DMF $(20 \mathrm{~mL})$ was added via syringe. The reaction mixture was heated to $100{ }^{\circ} \mathrm{C}$ for $6 \mathrm{~h}$ before being cooled to $\mathrm{rt}$. Standard aqueous workup followed by silica gel chromatography (hexanes:EtOAc, 8:1 v/v) gave pure $\mathbf{1 1}(5.30 \mathrm{~g}, 95 \%)$ as a colorless oil.

11: ${ }^{1} \mathrm{H} \mathrm{NMR}\left(\mathrm{CDCl}_{3}, 500 \mathrm{MHz}\right): \delta 7.70(\mathrm{~d}, 2 \mathrm{H}, J=8.3 \mathrm{~Hz})$, $7.29(\mathrm{~d}, 2 \mathrm{H}, J=8.1 \mathrm{~Hz}), 5.60-5.68(\mathrm{~m}, 1 \mathrm{H}), 5.13-5.20(\mathrm{~m}, 2 \mathrm{H})$, $4.75(\mathrm{~s}, 1 \mathrm{H}), 4.66(\mathrm{~s}, 1 \mathrm{H}), 3.82(\mathrm{~d}, 2 \mathrm{H}, J=6.4 \mathrm{~Hz}), 3.23(\mathrm{~m}, 2$ $\mathrm{H}), 2.42(\mathrm{~s}, 3 \mathrm{H}), 2.22(\mathrm{t}, 2 \mathrm{H}, J=8.1 \mathrm{~Hz}), 1.70(\mathrm{~s}, 3 \mathrm{H}) .{ }^{13} \mathrm{C}$ NMR $\left(\mathrm{CDCl}_{3}, 125 \mathrm{MHz}\right): \delta 143.2,142.4,137.2,133.2,129.7$, 127.1, 118.8, 112.0, 50.6, 45.8, 36.5, 22.4, 21.5. Anal. Calcd for $\mathrm{C}_{15} \mathrm{H}_{21} \mathrm{NO}_{2} \mathrm{~S}: \mathrm{C}, 64.48 ; \mathrm{H}, 7.58 ; \mathrm{N}, 5.01$. Found: $\mathrm{C}, 64.16 ; \mathrm{H}$, $7.65 ; \mathrm{N}, 4.98$.

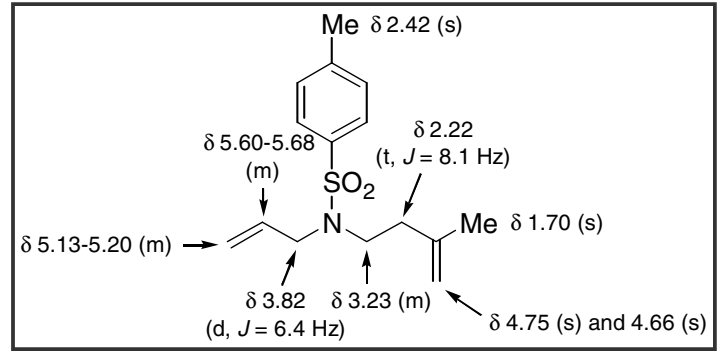

$N$-Allyl- $N$-methallyl- $p$-toluenesulfonamide (17)

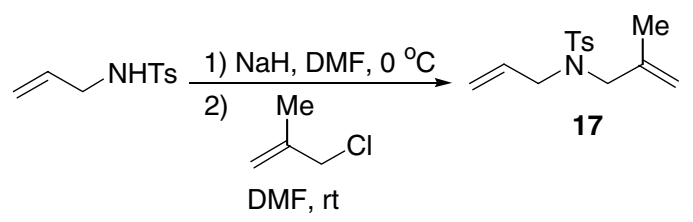

To a solution of $N$-allyl $p$-toluenesulfonamide $(4.23 \mathrm{~g}, 20 \mathrm{mmol})$ in DMF $(50 \mathrm{~mL})$ was added $\mathrm{NaH}(1.04 \mathrm{~g}, 60 \%$, $26 \mathrm{mmol})$ at $0{ }^{\circ} \mathrm{C}$ in one portion. After $\mathrm{H}_{2}$ evolution ceased, methallyl chloride $(2.40 \mathrm{~mL}, 2.17 \mathrm{~g}, 24 \mathrm{mmol})$ was 
added via syringe. The reaction mixture was stirred at $\mathrm{rt}$ for $12 \mathrm{~h}$. Standard aqueous workup followed by silica gel chromatography (hexanes:EtOAc, 8:1 v/v) gave pure $17(5.24 \mathrm{~g}, 99 \%)$ as a colorless oil.

17: ${ }^{1} \mathrm{H}$ NMR $\left(\mathrm{CDCl}_{3}, 500 \mathrm{MHz}\right): \delta 7.71(\mathrm{~d}, 2 \mathrm{H}, J=8.3 \mathrm{~Hz})$, $7.30(\mathrm{~d}, 2 \mathrm{H}, J=8.2 \mathrm{~Hz}), 5.50-5.60(\mathrm{~m}, 1 \mathrm{H}), 5.07-5.11(\mathrm{~m}, 2 \mathrm{H})$, $4.91(\mathrm{~s}, 1 \mathrm{H}), 4.85(\mathrm{~s}, 1 \mathrm{H}), 3.78(\mathrm{~d}, 2 \mathrm{H}, J=6.6 \mathrm{~Hz}), 3.71(\mathrm{~s}, 2$ $\mathrm{H}), 2.43(\mathrm{~s}, 3 \mathrm{H}), 1.70(\mathrm{~s}, 3 \mathrm{H}) .{ }^{13} \mathrm{C} \mathrm{NMR}\left(\mathrm{CDCl}_{3}, 125 \mathrm{MHz}\right): \delta$ $143.1,140.1,137.6,132.4,129.5,127.2,119.0,114.4,52.8,49.4$, 21.4, 19.7. Anal. Calcd for $\mathrm{C}_{14} \mathrm{H}_{19} \mathrm{NO}_{2} \mathrm{~S}: \mathrm{C}, 63.36 ; \mathrm{H}, 7.22 ; \mathrm{N}$, 5.28. Found: C, 63.23; H, 7.39; N, 5.22.

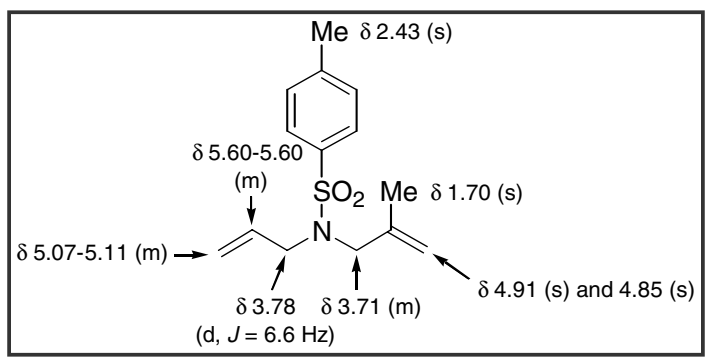

\section{Allyl 3-methyl-3-butenyl sulfone (18)}

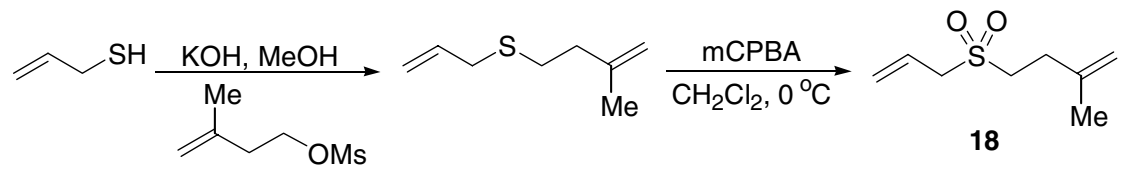

To a solution of allyl mercaptan $(800 \mu \mathrm{L}, 742 \mathrm{mg}, 80 \%, 8.0 \mathrm{mmol})$ and $\mathrm{KOH}(3.37 \mathrm{~g}, 60 \mathrm{mmol})$ in $\mathrm{MeOH}(10$ $\mathrm{mL}$ ) was added dropwise a solution of 3-methyl-3-butenyl methanesulfonate (1.97 g, $12 \mathrm{mmol})$ in $\mathrm{MeOH}(10$ $\mathrm{mL}$ ). After stirring at $\mathrm{rt}$ for $60 \mathrm{~min}$, the reaction was quenched with saturated aqueous $\mathrm{NH}_{4} \mathrm{Cl}$ and extracted with EtOAc $(2 \times 50 \mathrm{~mL})$. The combined organic extracts were washed with brine, dried $\left(\mathrm{Na}_{2} \mathrm{SO}_{4}\right)$ and concentrated to give the crude sulfide. The sulfide was then taken up with $\mathrm{CH}_{2} \mathrm{Cl}_{2}(30 \mathrm{~mL})$ and treated with $\mathrm{mCPBA}(3.47 \mathrm{~g}$, $70 \%, 14 \mathrm{mmol}$ ) at $0{ }^{\circ} \mathrm{C}$. After stirring at $0{ }^{\circ} \mathrm{C}$ for $60 \mathrm{~min}$, the reaction was quenched with saturated aqueous $\mathrm{NaHCO}_{3}$ and extracted with $\mathrm{CH}_{2} \mathrm{Cl}_{2}(30 \mathrm{~mL})$. The organic extracts were washed with $10 \% \mathrm{Na}_{2} \mathrm{~S}_{2} \mathrm{O}_{5}$ and brine, and dried $\left(\mathrm{Na}_{2} \mathrm{SO}_{4}\right)$. Purification by silica gel chromatography (hexanes: $\left.\mathrm{CH}_{2} \mathrm{Cl}_{2}, 1: 2 \mathrm{v} / \mathrm{v}\right)$ gave 18 (700 mg, 50 $\%$ based on allyl mercaptan) as a colorless oil.

18: ${ }^{1} \mathrm{H}$ NMR: $\delta$ 5.94-5.99 (m, $\left.1 \mathrm{H}\right), 5.45-5.53(\mathrm{~m}, 2 \mathrm{H}), 4.86(\mathrm{~s}$, $1 \mathrm{H}), 4.77(\mathrm{~s}, 1 \mathrm{H}), 3.74(\mathrm{~d}, 2 \mathrm{H}, J=7.4 \mathrm{~Hz}), 3.09(\mathrm{~m}, 2 \mathrm{H})$, $2.53(\mathrm{t}, 2 \mathrm{H}, J=8.4 \mathrm{~Hz}), 1.77(\mathrm{~s}, 3 \mathrm{H}) .{ }^{13} \mathrm{C}$ NMR: $\delta$ 141.4, 125.2, 124.6, 112.3, 57.8, 49.7, 29.5, 22.3. Anal. Calcd for $\mathrm{C}_{8} \mathrm{H}_{14} \mathrm{O}_{2} \mathrm{~S}: \mathrm{C}, 55.14 ; \mathrm{H}, 8.10$. Found: C, 54.80; H, 8.41.

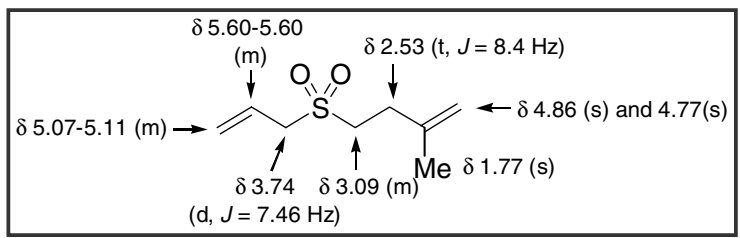

\section{2-Methyl-1,7-octadien-4-yl benzoate (19)}

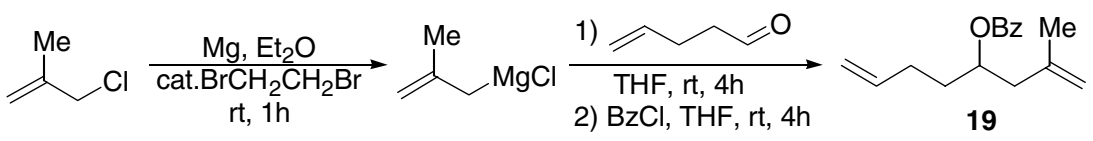

A flame-dried flask equipped with a reflux condenser was charged with magnesium powder (972 $\mathrm{mg}, 40 \mathrm{mmol})$. The flask was then dried on vacuum line with occasional and moderate heating with a heating gun for $3 \mathrm{~h}$ and charged with diethyl ether $(15 \mathrm{~mL})$ followed by 1, 2-dibromoethane $(86 \mu \mathrm{L}, 188 \mathrm{mg}, 1 \mathrm{mmol})$. After gas evolution ceased, 3-chloro-2-methylpropene $(988 \mu \mathrm{L}, 906 \mathrm{mg} 10 \mathrm{mmol})$ was added via syringe and the reaction mixture stirred at $\mathrm{rt}$ for $1 \mathrm{~h}$. The Grignard reagent was then transferred dropwide at $0{ }^{\circ} \mathrm{C}$ to a $50 \mathrm{~mL}$ flask containing 4-pentenal ( $421 \mathrm{mg}, 5 \mathrm{mmol})$ in THF $(20 \mathrm{~mL})$ and the reaction mixture stirred at $\mathrm{rt}$ for $4 \mathrm{~h}$. Benzoyl chloride $(672 \mu \mathrm{L}, 843 \mathrm{mg}, 6 \mathrm{mmol})$ was then added via syringe. After stirring at $\mathrm{rt}$ for $4 \mathrm{~h}$, the reaction mixture was quenched with saturated aqueous $\mathrm{NH}_{4} \mathrm{Cl}$ and extracted with EtOAc $(2 \times 50 \mathrm{~mL})$. The combined organic extracts were washed with brine and dried with anhydrous $\mathrm{Na}_{2} \mathrm{SO}_{4}$. Purification by silica gel chromatography (hexanes/EtOAc, 95:5 v/v) gave 19 (540 $\mathrm{mg}, 44 \%$ ) as a colorless oil.

19: ${ }^{1} \mathrm{H}$ NMR: $\delta 8.05(\mathrm{~d}, 2 \mathrm{H}, J=8.1 \mathrm{~Hz}), 7.56(\mathrm{t}, 1 \mathrm{H}, J=7.5$ $\mathrm{Hz}), 7.45$ (t, $2 \mathrm{H}, J=7.7 \mathrm{~Hz}), 5.81-5.86(\mathrm{~m}, 1 \mathrm{H}), 5.31-5.34(\mathrm{~m}, 1$ $\mathrm{H}), 4.97-5.05(\mathrm{~m}, 2 \mathrm{H}), 4.80(\mathrm{~s}, 1 \mathrm{H}), 4.77(\mathrm{~s}, 1 \mathrm{H}), 2.48(\mathrm{dd}, 1 \mathrm{H}$, $J=7.5,13.9 \mathrm{~Hz}), 2.35(\mathrm{dd}, 1 \mathrm{H}, J=5.5,13.9 \mathrm{~Hz}), 2.18(\mathrm{~m}, 2 \mathrm{H})$, 1.76-1.84 (m, $2 \mathrm{H}), 1.80(\mathrm{~s}, 3 \mathrm{H}) .{ }^{13} \mathrm{C} \mathrm{NMR}: \delta 166.1,141.6$, $137.8,132.8,130.6,129.6,128.3,115.0,113.6,72.3,42.9,33.3$,

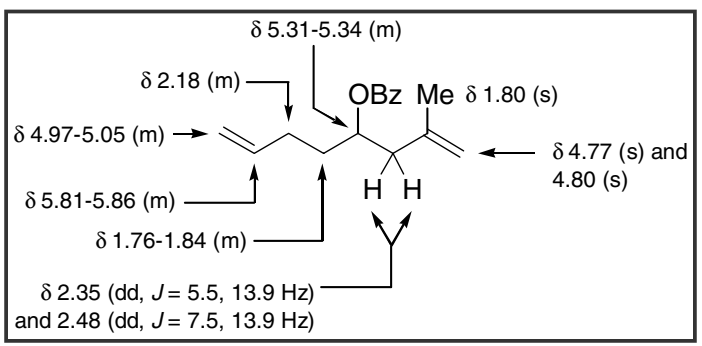


29.7, 22.6. Anal. Calcd for $\mathrm{C}_{16} \mathrm{H}_{20} \mathrm{O}_{2}$ : C, 78.65; H, 8.25. Found: C, 78.55; H, 8.35.

$N$-(3-Butenyl)- $N$-(3-methyl-3-butenyl)-p-toluenesulfonamide (20)

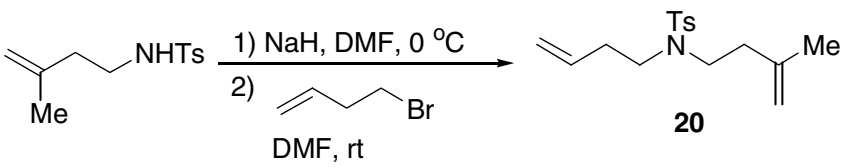

To a solution of $\mathrm{N}$-(3-methyl-3-butenyl)-p-toluenesulfonamide (1.51 g, $6.3 \mathrm{mmol})$ in DMF (40 mL) was added $\mathrm{NaH}(380 \mathrm{mg}, 60 \%, 9.5 \mathrm{mmol})$ in one portion at $0{ }^{\circ} \mathrm{C}$. After $\mathrm{H}_{2}$ evolution ceased, 4-bromobutene $(706 \mu \mathrm{L}, 939$ $\mathrm{mg}, 7.0 \mathrm{mmol}$ ) was added via syringe. The reaction mixture was stirred at $\mathrm{rt}$ for $18 \mathrm{~h}$. Standard aqueous workup followed by flash column chromatography on silica (hexanes:EtOAc, 8:1 v/v) gave pure $20(509 \mathrm{mg}, 28 \%)$ as a colorless oil.

20: ${ }^{1} \mathrm{H} \mathrm{NMR}\left(\mathrm{CDCl}_{3}, 500 \mathrm{MHz}\right): \delta 7.71(\mathrm{~d}, 2 \mathrm{H}, J=8.2 \mathrm{~Hz})$, $7.30(\mathrm{~d}, 2 \mathrm{H}, J=8.1 \mathrm{~Hz}), 5.69-5.77(\mathrm{~m}, 1 \mathrm{H}), 5.03-5.09(\mathrm{~m}, 2$ $\mathrm{H}), 4.77(\mathrm{~s}, 1 \mathrm{H}), 4.68(\mathrm{~s}, 1 \mathrm{H}), 3.20-3.27(\mathrm{~m}, 4 \mathrm{H}), 2.43$ (s, 3 $\mathrm{H}), 2.23-2.33(\mathrm{~m}, 4 \mathrm{H}), 1.73(\mathrm{~s}, 3 \mathrm{H}) .{ }^{13} \mathrm{C} \mathrm{NMR}\left(\mathrm{CDCl}_{3}, 125\right.$ $\mathrm{MHz}): \delta 143.1,142.4,137.1,134.7,129.6,127.1,117.1$, 112.0, 47.6, 46.8, 36.8, 33.2, 22.5, 21.5. Anal. Calcd for $\mathrm{C}_{16} \mathrm{H}_{23} \mathrm{NO}_{2} \mathrm{~S}: \mathrm{C}, 65.49 ; \mathrm{H}, 7.90 ; \mathrm{N}, 4.77$. Found: C, 65.21; H, $7.77 ; \mathrm{N}, 4.86$.

\section{3-Methyl-3-butenyl 1-phenyl-3-butenyl sulfone (21)}
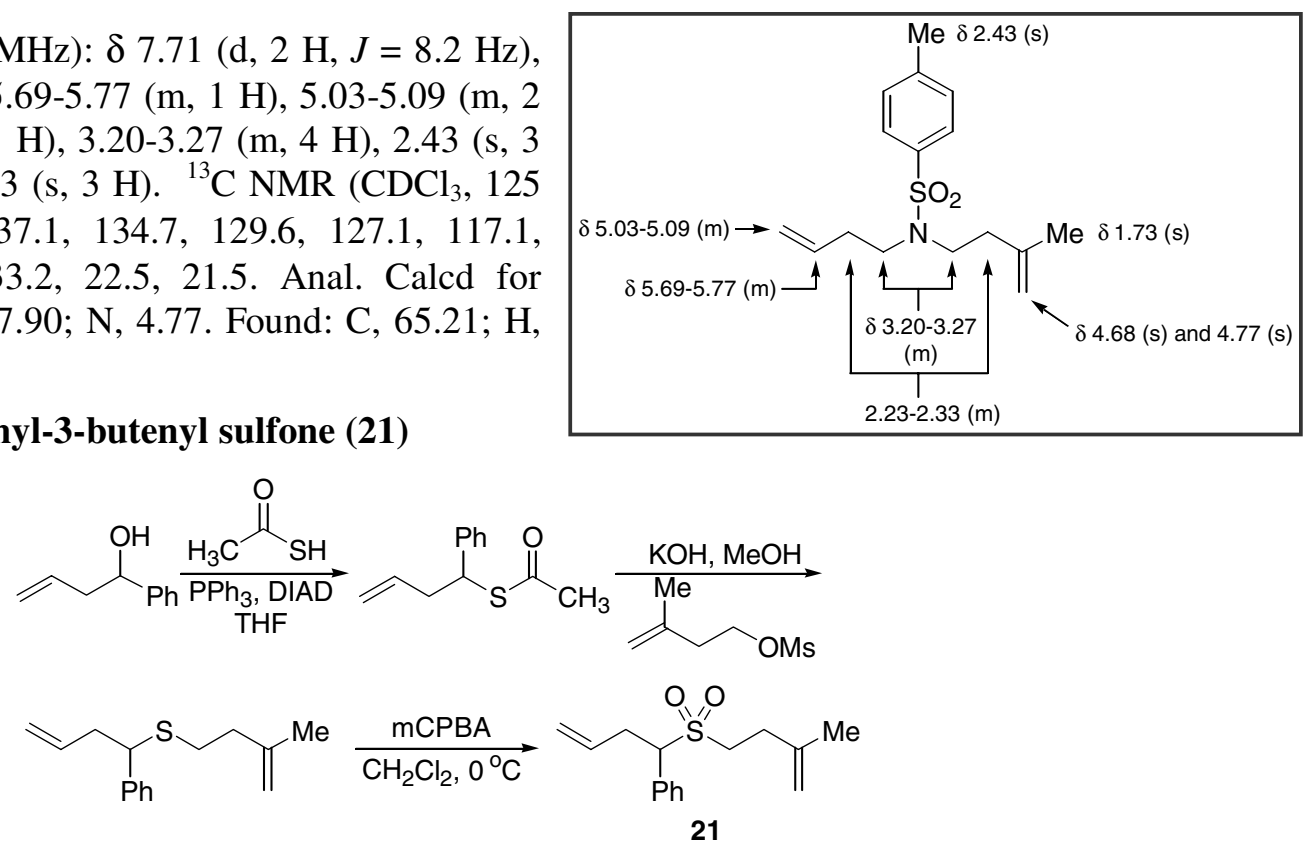

To a stirred solution of 1-phenyl-3-propen-1-ol (1.48 g, $10.0 \mathrm{mmol})$ and $\mathrm{Ph}_{3} \mathrm{P}(3.93 \mathrm{~g}, 15 \mathrm{mmol})$ in dry $\mathrm{THF}$ (30 $\mathrm{mL})$ was added dropwise by syringe diisopropyl azodicarboxylate $(2.50 \mathrm{~mL}, 15 \mathrm{mmol})$ at $0{ }^{\circ} \mathrm{C}$. After stirring for $10 \mathrm{~min}$ at $0{ }^{\circ} \mathrm{C}$, thiolacetic acid $(1.07 \mathrm{~mL}, 15 \mathrm{mmol})$ was added dropwise and the resulting reaction mixture stirred at $\mathrm{rt}$ for $16 \mathrm{~h}$. The solvent and volatiles were then removed under vacuum. The crude reaction mixture was triturated with hexanes $(50 \mathrm{~mL})$ and the precipitate filtered off. The crude product was purified by flash chromatography on silica gel (hexanes $/ \mathrm{CH}_{2} \mathrm{Cl}_{2}, 3: 1$ then $\left.2: 1 \mathrm{v} / \mathrm{v}\right)$ to give the corresponding thiolester $(1.38 \mathrm{~g}$, $67 \%)$ as a thick oil. ${ }^{1} \mathrm{H}$ NMR $\left(\mathrm{CDCl}_{3}, 500 \mathrm{MHz}\right): \delta$ 7.23-7.34 (m, $\left.5 \mathrm{H}\right), 5.66-5.74(\mathrm{~m}, 1 \mathrm{H}), 5.02-5.10(\mathrm{~m}, 2 \mathrm{H})$, $4.66(\mathrm{t}, 1 \mathrm{H}, J=7.7 \mathrm{~Hz}), 2.66-2.75(\mathrm{~m}, 2 \mathrm{H}), 2.31(\mathrm{~s}, 3 \mathrm{H}) .{ }^{13} \mathrm{C} \mathrm{NMR}\left(\mathrm{CDCl}_{3}, 125 \mathrm{MHz}\right): \delta 194.46,141.18$, 134.61, 128.49, 127.65, 127.28, 117.60, 47.53, 40,31, 30.40. $\mathrm{C}_{12} \mathrm{H}_{14} \mathrm{OS}: \mathrm{C}, 69.86 ; \mathrm{H}, 6.84$. Found: C, 69.77; H, 6.49 .

A solution of the thiolester $(825 \mathrm{mg}, 4 \mathrm{mmol})$ in $\mathrm{MeOH}(10 \mathrm{~mL})$ was then treated with $\mathrm{KOH}(1.35 \mathrm{~g}, 24 \mathrm{mmol})$ followed by 3-methyl-3-butenyl methanesufonate $(788 \mathrm{mg}, 4.8 \mathrm{mmol})$ in $\mathrm{MeOH}(5 \mathrm{~mL})$. After stirring at $\mathrm{rt}$ for $90 \mathrm{~min}$, the reaction was quenched by saturated aqueous $\mathrm{NH}_{4} \mathrm{Cl}$ and extracted with EtOAc $(2 \times 50 \mathrm{~mL})$. The combined organic extracts were washed with brine, dried $\left(\mathrm{Na}_{2} \mathrm{SO}_{4}\right)$ and concentrated. Purification by flash column chromatography on silica (hexanes/ $\mathrm{CH}_{2} \mathrm{Cl}_{2}, 2: 1 \mathrm{v} / \mathrm{v}$ ) gave corresponding sulfide $(768 \mathrm{mg}, 83 \%$ ) as a pale yellow oil. ${ }^{1} \mathrm{H}$ NMR: $\delta$ 7.23-7.37 (m, $\left.5 \mathrm{H}\right)$, 5.69-5.75 (m, $\left.1 \mathrm{H}\right)$, 5.00-5.06 (m, $\left.2 \mathrm{H}\right), 4.72(\mathrm{~s}, 1 \mathrm{H}), 4.64(\mathrm{~s}, 1 \mathrm{H})$, $3.86(\mathrm{t}, 1 \mathrm{H}, J=7.5 \mathrm{~Hz}), 2.62-2.64(\mathrm{~m}, 2 \mathrm{H}), 2.36-2.44(\mathrm{~m}, 2 \mathrm{H}), 2.15-2.21(\mathrm{~m}, 2 \mathrm{H}), 1.64(\mathrm{~s}, 3 \mathrm{H}) .{ }^{13} \mathrm{C} \mathrm{NMR}: \delta$ $144.1,142.2,135.4,128.4,127.9,127.1,116.9,111.1,49.7,40.9,37.5,29.3,22.1$.

To a stirred solution of the sulfide $(768 \mathrm{mg}, 3.3 \mathrm{mmol})$ in $\mathrm{CH}_{2} \mathrm{Cl}_{2}(20 \mathrm{~mL})$ was added $0{ }^{\circ} \mathrm{C}$ 3-chloroperbenzoic acid $\left(1.63 \mathrm{~g}, \sim 70 \%, 6.6 \mathrm{mmol}\right.$,) in one portion and the reaction mixture was stirred at $0{ }^{\circ} \mathrm{C}$ for $90 \mathrm{~min}$. The reaction was quenched with saturated aqueous $\mathrm{NaHCO}_{3}$ and extracted with $\mathrm{CH}_{2} \mathrm{Cl}_{2}(30 \mathrm{~mL})$. The combined 
organic extracts were washed with $10 \%$ aqueous $\mathrm{Na}_{2} \mathrm{~S}_{2} \mathrm{O}_{5}$ and brine, and dried $\left(\mathrm{Na}_{2} \mathrm{SO}_{4}\right)$. After concentration to dryness, the crude product was purified by flash column chromatography on silica (hexanes: $\mathrm{CH}_{2} \mathrm{Cl}_{2}$ 1:4) to give 21 (470 $\mathrm{mg}, 54 \%)$ as a slightly yellow oil.

21: ${ }^{1} \mathrm{H}$ NMR: $\delta$ 7.38-7.46 (m, $\left.5 \mathrm{H}\right)$, 5.53-5.61 (m, $\left.1 \mathrm{H}\right), 5.00-$ $5.12(\mathrm{~m}, 2 \mathrm{H}), 4.75(\mathrm{~s}, 1 \mathrm{H}), 4.61(\mathrm{~s}, 1 \mathrm{H}), 4.09(\mathrm{dd}, 1 \mathrm{H}, J=4$, $11.2 \mathrm{~Hz}), 3.16-3.21(\mathrm{~m}, 1 \mathrm{H}), 2.73-2.92(\mathrm{~m}, 3 \mathrm{H}), 2.31-2.47$ $(\mathrm{m}, 2 \mathrm{H}), 1.64(\mathrm{~s}, 3 \mathrm{H}) .{ }^{13} \mathrm{C}$ NMR: $\delta 141.5,132.8,132.5$, 129.5, 129.2, 129.1, 118.7, 112.1, 68.4, 49.3, 31.6, 29.3, 22.2. Anal. Calcd for $\mathrm{C}_{15} \mathrm{H}_{20} \mathrm{O}_{2} \mathrm{~S}$ : C, 68.14; H, 7.62. Found: C,

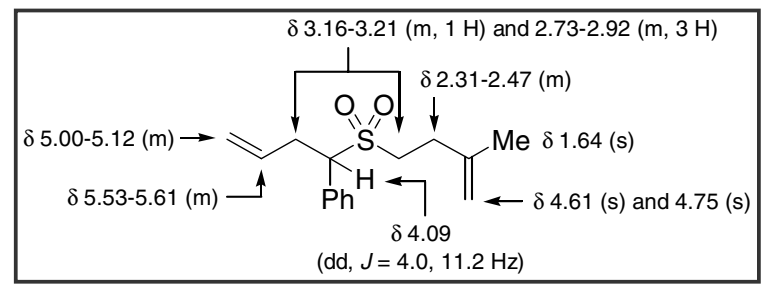
$68.12 ; \mathrm{H}, 7.65$.

\section{1-Phenyl-3-butenyl methacrylate (28)}

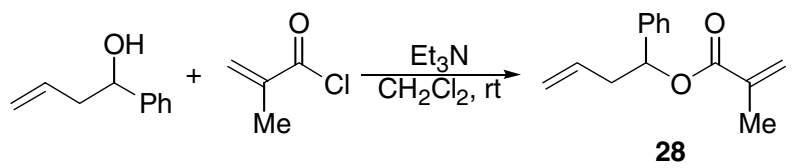

To a stirred solution of 1-phenyl-3-buten-1-ol (742 mg, $5 \mathrm{mmol})$ in $\mathrm{CH}_{2} \mathrm{Cl}_{2}(20 \mathrm{~mL})$ was added $\mathrm{Et}_{3} \mathrm{~N}(1.4 \mathrm{~mL}, 10$ mmol) and methacryloyl chloride $(580 \mu \mathrm{L}, 627 \mathrm{mg}, 6 \mathrm{mmol})$ via syringe. The reaction mixture was then stirred at $\mathrm{rt}$ for $3 \mathrm{~h}$. Standard aqueous workup followed by flash chromatography on silica (hexanes: $\mathrm{CH}_{2} \mathrm{Cl}_{2}, 2: 1 \mathrm{v} / \mathrm{v}$ ) gave pure 28 (397 $\mathrm{mg}, 37 \%)$.

28: ${ }^{1} \mathrm{H}$ NMR $\left(\mathrm{CDCl}_{3}, 500 \mathrm{MHz}\right): \delta 7.27-7.40(\mathrm{~m}, 5 \mathrm{H}), 6.18(\mathrm{~s}, 1 \mathrm{H})$, $5.87(\mathrm{t}, 1 \mathrm{H}, J=7.3 \mathrm{~Hz}), 5.71-5.76(\mathrm{~m}, 1 \mathrm{H}), 5.58(\mathrm{~s}, 1 \mathrm{H}), 5.05-5.11$ $(\mathrm{m}, 2 \mathrm{H}), 2.59-2.73(\mathrm{~m}, 2 \mathrm{H}), 1.97(\mathrm{~s}, 3 \mathrm{H}) .{ }^{13} \mathrm{C} \mathrm{NMR}\left(\mathrm{CDCl}_{3}, 125\right.$ $\mathrm{MHz}): \delta 166.5,140.2,136.5,133.3,128.4,127.9,126.4,125.5,118.1$, 75.4, 40.9, 18.3. Anal. Calcd for $\mathrm{C}_{14} \mathrm{H}_{16} \mathrm{O}_{2}$ : C, 77.75; H, 7.46. Found:

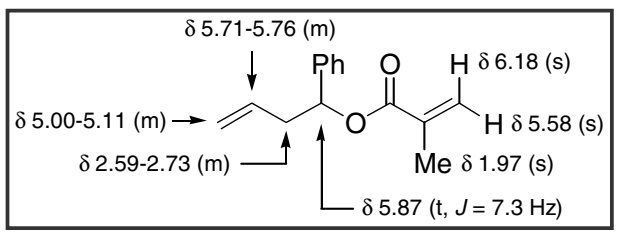
C, 77.61; H, 7.54.

\section{$N$, $N$-Bis(3-methyl-3-butenyl) )-p-toluenesulfonamide (30)}

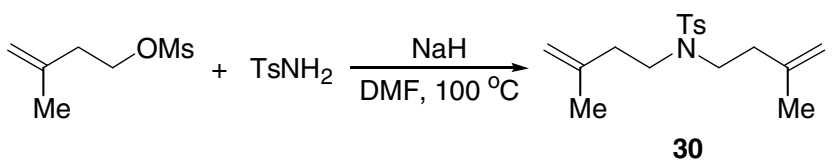

To a solution of $\mathrm{TsNH}_{2}(7.70 \mathrm{~g}, 45 \mathrm{mmol})$ in $\mathrm{DMF}(100 \mathrm{~mL})$ was added at $0{ }^{\circ} \mathrm{C} \mathrm{NaH}(2.00 \mathrm{~g}, 60 \%, 50 \mathrm{mmol})$ in one portion. After $\mathrm{H}_{2}$ evolution ceased, a solution of 3-methyl-3-butenyl methanesulfonate $(6.85 \mathrm{~g}, 40 \mathrm{mmol})$ in DMF (40mL) was added via syringe. he reaction mixture was heated to $100{ }^{\circ} \mathrm{C}$ for $12 \mathrm{~h}$ before cooled to rt. Standard aqueous work followed by flash column chromatography on silica (hexanes:EtOAc, 8:1 v/v) gave 30 (2.25 g, 17\%) and $N$-(3-methyl-3-butenyl) $p$-toluenesulfonamide (5.56 g, 58\%).

30: ${ }^{1} \mathrm{H}$ NMR $\left(\mathrm{CDCl}_{3}, 500 \mathrm{MHz}\right): \delta 7.71(\mathrm{~d}, 2 \mathrm{H}, J=8.1 \mathrm{~Hz}), 7.30(\mathrm{~d}, 2$ $\mathrm{H}, J=8.1 \mathrm{~Hz}), 4.78(\mathrm{~s}, 2 \mathrm{H}), 4.68(\mathrm{~s}, 2 \mathrm{H}), 3.26(\mathrm{~m}, 4 \mathrm{H}), 2.43(\mathrm{~s}, 3 \mathrm{H})$, $2.24(\mathrm{t}, 4 \mathrm{H}, J=8.2 \mathrm{~Hz}), 1.73(\mathrm{~s}, 6 \mathrm{H}) .{ }^{13} \mathrm{C} \mathrm{NMR}\left(\mathrm{CDCl}_{3}, 125 \mathrm{MHz}\right): \delta$ $143.1,142.4,137.1,129.6,127.1,112.0,46.7,36.8,22.5,21.5$. Anal. Calcd for $\mathrm{C}_{17} \mathrm{H}_{25} \mathrm{NO}_{2} \mathrm{~S}: \mathrm{C}, 66.41 ; \mathrm{H}, 8.20 ; \mathrm{N}, 4.56$. Found: $\mathrm{C}, 66.14 ; \mathrm{H}$, $7.89 ; \mathrm{N}, 4.48$.

\section{Synthesis of Polymer-Bound Styrene Ligand 8.}

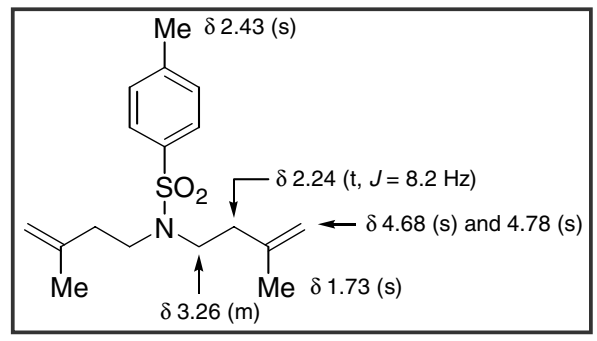




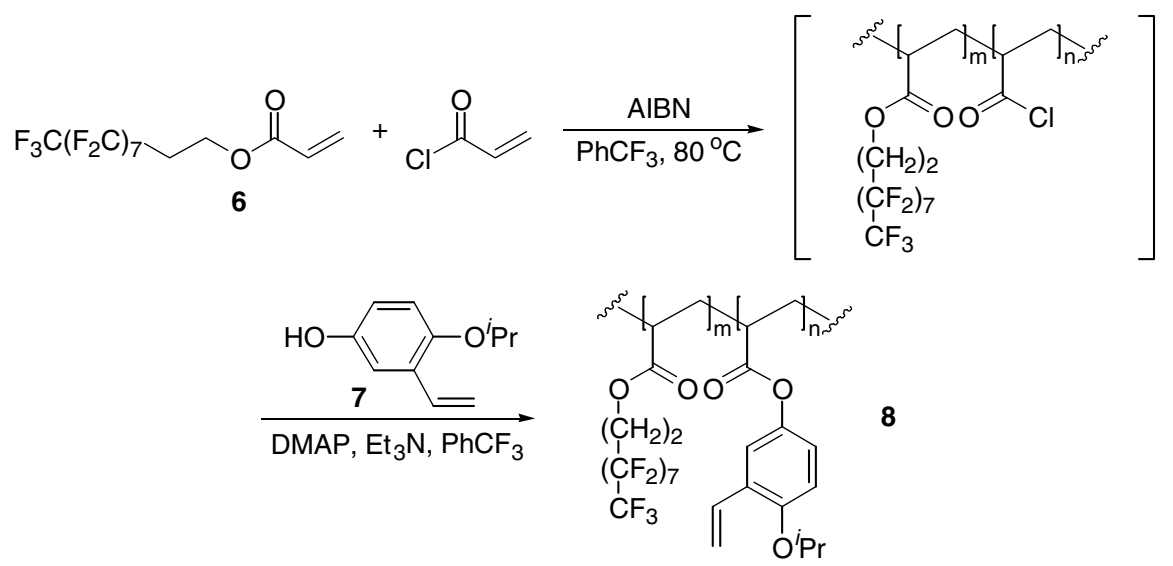

A $10 \mathrm{~mL}$ flame-dried Schlenk flask was charged with heptadecafluorodecyl acrylate 6 (950 $\mu \mathrm{L}, 1.55 \mathrm{~g}, 3.0$ mmol) and $\mathrm{PhCF}_{3}(3 \mathrm{~mL})$. Acryoyl chloride $(41 \mu \mathrm{L}, 45.3 \mathrm{mg}, 0.5 \mathrm{mmol}$,) was then added via syringe followed by AIBN (99 mg, $0.6 \mathrm{mmol}, 20 \mathrm{~mol} \%$ ) under an Ar atmosphere. The flask was sealed and immersed in an oil bath preheated to $80{ }^{\circ} \mathrm{C}$. After stirring for $20 \mathrm{~h}$ at this temperature, the reaction was cooled to rt. DMAP (12 mg, $0.1 \mathrm{mmol})$ and $\mathrm{Et}_{3} \mathrm{~N}(111 \mu \mathrm{L}, 81 \mathrm{mg}, 0.8 \mathrm{mmol})$ were added followed by a solution of 5-hydroxy-2isopropoxylstyrene $7^{1}(89 \mathrm{mg}, 0.5 \mathrm{mmol})$ in $\mathrm{PhCF}_{3}(1 \mathrm{~mL})$. The reaction mixture was stirred at $\mathrm{rt}$ under Ar for $18 \mathrm{~h}$ and concentrated to dryness in vacuo. The crude reaction mixture was partitioned in FC-72 $(20 \mathrm{~mL})$ and $\mathrm{CH}_{2} \mathrm{Cl}_{2}(20 \mathrm{~mL})$. The FC-72 layer was separated and washed with $\mathrm{CH}_{2} \mathrm{Cl}_{2}(2 \times 20 \mathrm{~mL})$. After concentration and drying on vacuum line, polymer 8 was obtained as a glassy white powder (1.57 g, 97\%). Analysis by $500 \mathrm{MHz}$ ${ }^{1} \mathrm{H}$ NMR $\left(\mathrm{CDCl}_{3}, 50{ }^{\circ} \mathrm{C}\right)$ revealed a ratio of about 10:1 between the fluoroalkyl unit and the styrene ligand, pointing a loading of $0.19 \mathrm{mmol} / \mathrm{g}$.

\section{Polymer-Bound Ru Carbene Complex 1: Synthesis and Structural Characterization.}

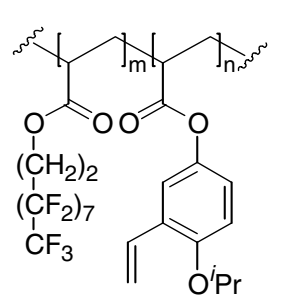

8
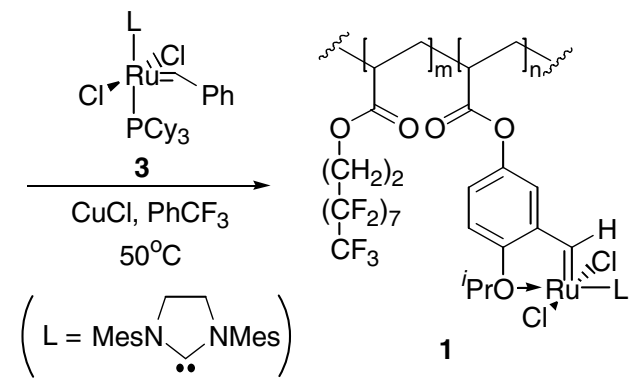

[The procedure for the preparation of $\mathbf{1}$ described below is representative of all other experiments of Tables 1 and 2 of the text, with the quantities of the appropriate reactants and solvents adjusted in accordance with the scales and conditions specified for each reaction.]

A $5 \mathrm{~mL}$ flame-dried Schlenk flask was charged with $8(56 \mathrm{mg}, 0.0106 \mathrm{mmol})$ and degassed three times by evacuation and then filling with Ar. Ruthenium carbene complex 3 (10 mg, $0.015 \mathrm{mmol}), \mathrm{CuCl}(1.0 \mathrm{mg}, 0.01$ mmol) were added under argon. $\mathrm{PhCF}_{3}(1 \mathrm{~mL})$ was added via syringe and the flask was sealed and heated to 50 ${ }^{\circ} \mathrm{C}$ (bath temperature) for $1.5 \mathrm{~h}$. After cooling to $\mathrm{rt}$, the reaction mixture was concentrated to dryness under vacuum and partitioned in FC-72 $(5 \mathrm{~mL})$ and EtOAc $(5 \mathrm{~mL})$. The FC-72 layer was separated and the EtOAc layer extracted with FC-72 (2 x $3 \mathrm{~mL})$. The FC-72 extracts were combined and washed with EtOAc $(5 \mathrm{~mL})$. After removal of the solvent and drying on vacuum line, $1(62 \mathrm{mg})$ was obtained as a dark green powder. ${ }^{1} \mathrm{H}$ NMR $\left(\mathrm{CDCl}_{3}, 50{ }^{\circ} \mathrm{C}\right)$ analysis revealed a conversion of greater than $90 \%$ of the styrene ligand. Partial ${ }^{1} \mathrm{HNMR}$ $\left(\mathrm{CDCl}_{3}, 500 \mathrm{MHz}\right.$, with presaturation of the polymer backbone signals): $\delta 16.42$ (br, $\left.1 \mathrm{H}, \mathrm{Ru}=\mathrm{CHAr}\right), 4.81$ (br, 1 $\mathrm{H}, \mathrm{OCHMe}_{2}$ ), 4.16-4.34 (br, $\sim 20 \mathrm{H}, \mathrm{OCH}_{2} \mathrm{CH}_{2}$ ). The structure of 1 was characterized by its characteristic carbene signal at $\delta 16.42$, which is the only carbene peak observed, as well as the methine proton peak at $\delta 4.81$ of the Ru-bound isopropoxy ligand. The structural assignment was further secured by comparison with those of the original Hoveyda-Grubbs' catalyst $\mathbf{5}^{3}$ ( $\delta 16.56$ of $\mathrm{Ru}=\mathrm{CHAr}$ and 4.90 of $\mathrm{OCHMe}_{2}$ ). NMR peaks attributable to structure $1 \cdot \mathrm{PCy}_{3}$ (cf. the known carbene $5 \cdot \mathrm{PCy}_{3}{ }^{4}$ ) were not detected. 

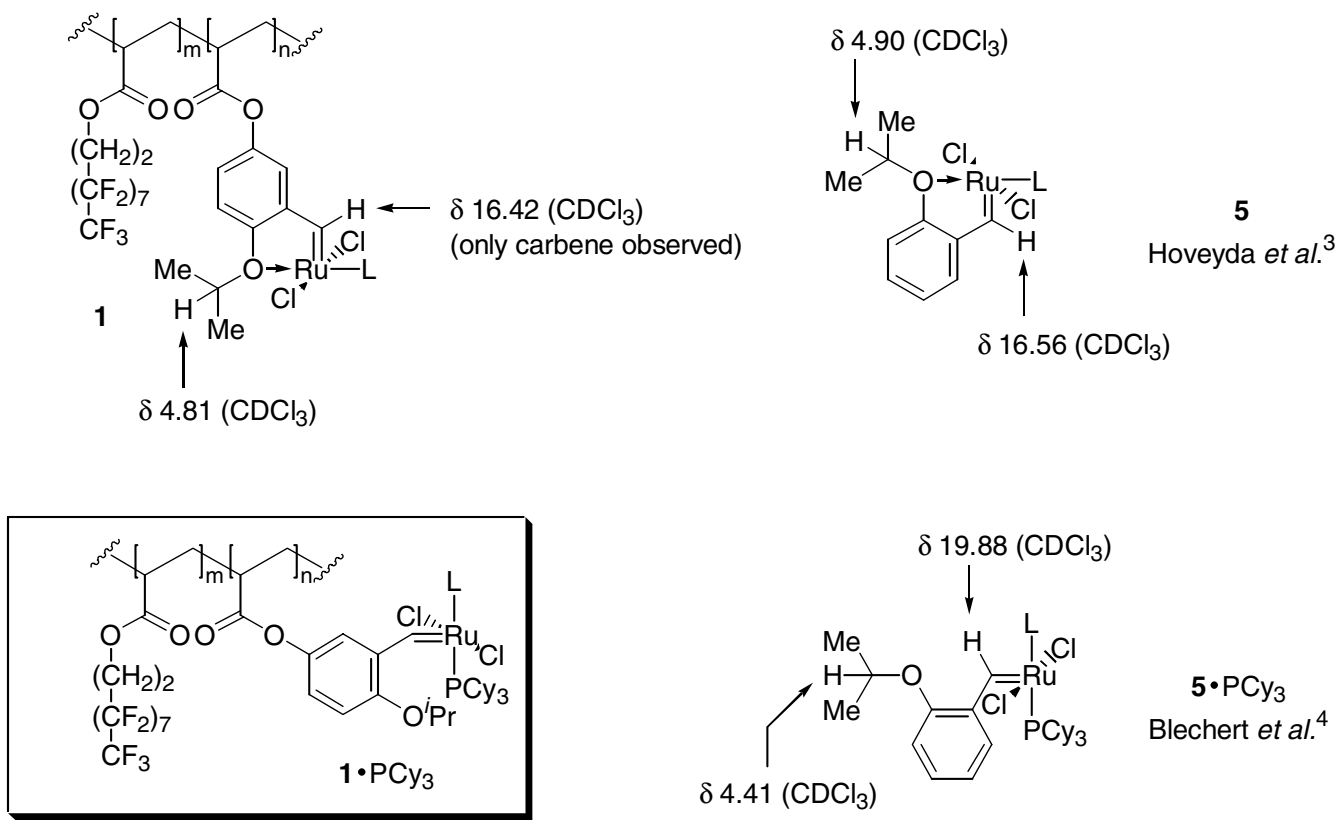

not formed

\section{General Procedure for the Recycling and Reuse of Catalyst 1 in Ring-closing Metathesis (RCM)}

\section{RCM of Diene 9.}

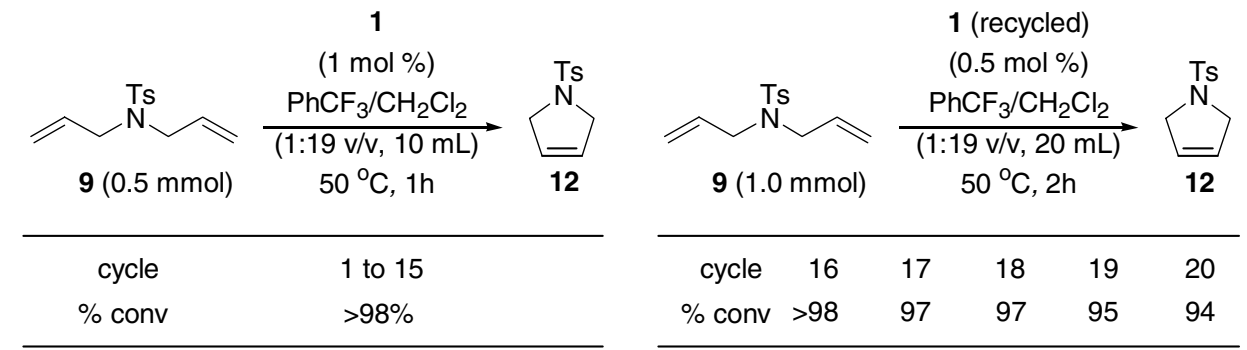

Catalyst 1, prepared according to the general procedure from $28 \mathrm{mg}(0.0053 \mathrm{mmol})$ of $\mathbf{8}, 5.0 \mathrm{mg}(0.0075 \mathrm{mmol})$ of 3 and $0.5 \mathrm{mg}(0.005 \mathrm{mmol})$ of $\mathrm{CuCl}$, was placed in a $50 \mathrm{~mL}$ flask equipped with a reflux condenser. After the flask was degassed three times by evacuation and then filling with $\mathrm{Ar}, \mathrm{PhCF}_{3}(0.5 \mathrm{~mL})$ and $\mathrm{CH}_{2} \mathrm{Cl}_{2}(4.5 \mathrm{~mL})$ were was added to dissolve the catalyst followed by $N$-tosyldiallylamine 9 (126 $\mathrm{mg}, 0.50 \mathrm{mmol})$ dissolved in $\mathrm{CH}_{2} \mathrm{Cl}_{2}(5 \mathrm{~mL})$. After heating to reflux (bath temperature $45-50^{\circ} \mathrm{C}$ ) for $1 \mathrm{~h}$, the reaction mixture was cooled to $\mathrm{rt}$ and concentrated to dryness under vacuum.

General procedure for product isolation and catalyst recycling by fluorous extraction. The crude reaction mixture was partitioned in FC-72 $(5 \mathrm{~mL})$ and EtOAc $(5 \mathrm{~mL})$. The FC-72 layer was separated and the EtOAc layer extracted with FC-72 (3 mL). The FC-72 extracts were combined and washed with EtOAc $(3 \mathrm{~mL})$. After concentration of the combined EtOAc extracts, the crude reaction product was analyzed by $500 \mathrm{MHz}{ }^{1} \mathrm{H}$ NMR which indicated complete conversion of diene 9 and clean, essentially quantitative formation of the known cyclized product 12. ${ }^{5}$ 12: ${ }^{1} \mathrm{H} \mathrm{NMR}\left(\mathrm{CDCl}_{3}, 500 \mathrm{MHz}\right): \delta 7.73(\mathrm{~d}, 2 \mathrm{H}, J=8.3 \mathrm{~Hz}), 7.33(\mathrm{~d}, 2 \mathrm{H}, J=8.1 \mathrm{~Hz})$, $5.66(\mathrm{~s}, 2 \mathrm{H}), 4.13(\mathrm{~s}, 4 \mathrm{H}), 2.44(\mathrm{~s}, 3 \mathrm{H})$. The FC-72 extracts were concentrated under reduced pressure. After drying on vacuum line, the recycled catalyst was used directly in a subsequent RCM reaction.

A second run of the RCM of $\mathbf{9}$ was performed in exactly the same way as described for the first run using the recycled catalyst. After fluorous extraction of the reaction mixture as described above, ${ }^{1} \mathrm{H}-\mathrm{NMR}$ analysis of the crude reaction product revealed a complete conversion of the diene 9 and quantitative formation of 12. This reaction was repeated 13 more times, each using the catalyst recycled from the previous run. This was continued for another 5 cycles (cycles 16 to 20) using $1.0 \mathrm{mmol}$ of diene 9 in $\mathrm{PhCF}_{3}(1: 19 \mathrm{v} / \mathrm{v}, 20 \mathrm{~mL}$ ) with the reaction time being $2 \mathrm{~h}$ for each cycle. The results were listed in Table 1 of the text. 
RCM of Diene 10.

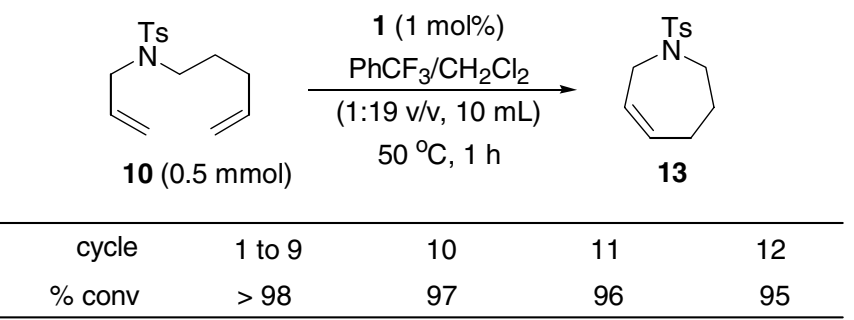

Catalyst 1, prepared according to the general procedure from $28 \mathrm{mg}(0.0050 \mathrm{mmol})$ of $\mathbf{8}, 5.0 \mathrm{mg}(0.0075 \mathrm{mmol})$ of 3 and $0.5 \mathrm{mg}(0.005 \mathrm{mmol})$ of $\mathrm{CuCl}$, was placed in a $50 \mathrm{~mL}$ flask equipped with a reflux condenser. After the flask was degassed three times by evacuation and then filling with $\mathrm{Ar}, \mathrm{PhCF}_{3}(0.5 \mathrm{~mL})$ was added to dissolve the catalyst followed by diene 10 (140 mg, $0.50 \mathrm{mmol})$ dissolved in $\mathrm{CH}_{2} \mathrm{Cl}_{2}(9.5 \mathrm{~mL})$. After heating to reflux (bath temperature $45-50^{\circ} \mathrm{C}$ ) for $1 \mathrm{~h}$, the reaction mixture was cooled to $\mathrm{rt}$ and concentrated to dryness under vacuum. After fluorous extraction of the reaction mixture following the general procedure, the crude reaction product was analyzed by $500 \mathrm{M} \mathrm{Hz}{ }^{1} \mathrm{H}$ NMR which indicated complete conversion of the diene $\mathbf{1 0}$ and clean and quantitative formation of the known cyclized product 13. ${ }^{6} \mathbf{1 3}:{ }^{1} \mathrm{H} \mathrm{NMR}\left(\mathrm{CDCl}_{3}, 500 \mathrm{MHz}\right): \delta 7.69(\mathrm{~d}, 2 \mathrm{H}, J$ $=8.2 \mathrm{~Hz}), 7.29(\mathrm{~d}, 2 \mathrm{H}, J=8.1 \mathrm{~Hz}), 5.76-5.80(\mathrm{~m}, 1 \mathrm{H}), 5.64-5.68(\mathrm{~m}, 1 \mathrm{H}), 3.84(\mathrm{dd}, 2 \mathrm{H}, J=0.9,4.8 \mathrm{~Hz}), 3.40$ $(\mathrm{t}, 2 \mathrm{H}, J=6.1 \mathrm{~Hz}), 2.43(\mathrm{~s}, 3 \mathrm{H}), 2.17-2.21(\mathrm{~m}, 2 \mathrm{H}), 1.81$ (quint, $2 \mathrm{H}, J=6.0 \mathrm{~Hz}$ ). The FC-72 extracts were concentrated under reduced pressure. After drying on vacuum line, the recycled catalyst was used directly in a subsequent RCM reaction.

A second run of the RCM of $\mathbf{1 0}$ was performed in exactly the same way as described for the first run using the recycled catalyst. After fluorous extraction of the reaction mixture following the general procedure, ${ }^{1} \mathrm{H}-$ NMR analysis of the crude reaction product revealed a complete conversion of the diene $\mathbf{1 0}$ and quantitative formation of 13. This reaction was repeated 10 more times, each using the catalyst recycled from the previous run. The results were listed in Table 1 of the text.

\section{RCM of Diene 10 under Fluorous Biphasic Conditions}

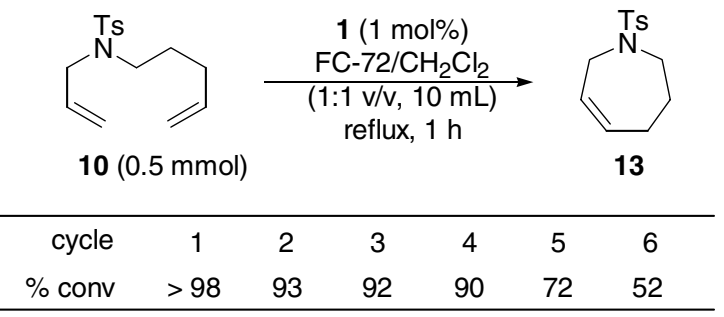

Catalyst 1, prepared according to the general procedure from $28 \mathrm{mg}(0.0050 \mathrm{mmol})$ of $\mathbf{8}, 5.0 \mathrm{mg}(0.0075 \mathrm{mmol})$ of 3 and $0.5 \mathrm{mg}(0.005 \mathrm{mmol})$ of $\mathrm{CuCl}$, was placed in a $50 \mathrm{~mL}$ flask equipped with a reflux condenser. After the flask was degassed three times by evacuation and then filling with Ar, FC-72 (5 mL, dried over $4 \AA$ molecular sieves and freshly distilled under an Ar atmosphere before use) was added to dissolve the catalyst followed by diene 10 (140 mg, $0.50 \mathrm{mmol}$ ) dissolved in $\mathrm{CH}_{2} \mathrm{Cl}_{2}(5 \mathrm{~mL})$. The reaction mixture was then heated to reflux (bath temperature $45-50^{\circ} \mathrm{C}$ ), resulting in the formation of a greenish creamy emulsion. After being refluxed for $1 \mathrm{~h}$, the reaction mixture was cooled to $\mathrm{rt}$ and evaporated to dryness under vacuum. After fluorous extraction of the reaction mixture following the general procedure, the crude reaction product was analyzed by $500 \mathrm{MHz}{ }^{1} \mathrm{H}$ NMR which indicated complete conversion of diene $\mathbf{1 0}$ and quantitative formation of $\mathbf{1 3}$. This reaction was repeated for 5 more cycles, each using the catalyst recycled from a previous run. Conversions for cycles 2-6 were $93 \%, 92 \%, 90 \%, 72 \%$ and $52 \%$, respectively. The gradual and significant diminishment in the conversion of $\mathbf{1 0}$ may be attributed to the biphasic nature of the reaction. Phase separation of the rebounding ligand of $\mathbf{8}$ in the FC-phase and the catalytic species in the $\mathrm{CH}_{2} \mathrm{Cl}_{2}$ phase may be the reasons for the gradual decomposition of the catalyst.

\section{RCM of Diene 11}




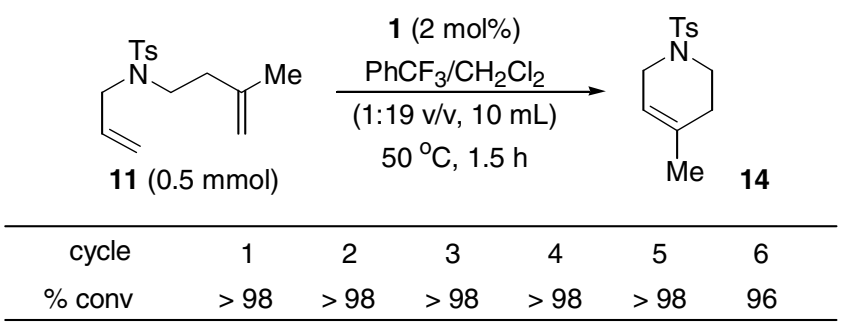

Catalyst 1, prepared according to the general procedure from $56 \mathrm{mg}(0.010 \mathrm{mmol})$ of $\mathbf{8}, 10 \mathrm{mg}(0.015 \mathrm{mmol})$ of 3 and $1.0 \mathrm{mg}(0.010 \mathrm{mmol})$ of $\mathrm{CuCl}$, was placed in a $50 \mathrm{~mL}$ flask equipped with a reflux condenser and the flask was degassed three times by evacuation and then filling with $\mathrm{Ar}$. $\mathrm{PhCF}_{3}(0.5 \mathrm{~mL})$ was then added to dissolve the catalyst followed by diene $11(140 \mathrm{mg}, 0.50 \mathrm{mmol})$ in $\mathrm{CH}_{2} \mathrm{Cl}_{2}(9.5 \mathrm{~mL})$. After heating to reflux (bath temperature $45-50{ }^{\circ} \mathrm{C}$ ) for $1.5 \mathrm{~h}$, the reaction mixture was cooled to $\mathrm{rt}$ and concentrated to dryness under vacuum. After fluorous extraction of the reaction mixture following the general procedure, the crude reaction product was analyzed by $500 \mathrm{M} \mathrm{Hz}{ }^{1} \mathrm{H}$ NMR which indicated complete conversion of the diene $\mathbf{1 1}$ and clean

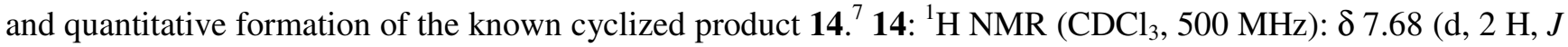
$=8.2 \mathrm{~Hz}), 7.32(\mathrm{~d}, 2 \mathrm{H}, J=8.1 \mathrm{~Hz}), 5.31(\mathrm{~m}, 1 \mathrm{H}), 3.53(\mathrm{~m}, 2 \mathrm{H}), 3.17(\mathrm{t}, 2 \mathrm{H}, J=5.8 \mathrm{~Hz}), 2.43(\mathrm{~s}, 3 \mathrm{H}), 2.11$ (bs, $2 \mathrm{H}), 1.66$ (s, $3 \mathrm{H})$.

This reaction was repeated 5 more times, each using the catalyst recycled from the previous run. The results were listed in Table 1 of the text.

To further test the limit of the recyclability of $\mathbf{1}$, the catalyst recycled from run 6 was reused for two more runs of the RCM of $\mathbf{1 1}$ in exactly the same way as in the previous runs. The conversion of $\mathbf{1 1}$ dropped to $94 \%$ and 90 $\%$ for run 7 and run 8 , respectively. The recycled catalyst was then treated with another portion of $\mathbf{3}$ in the presence of $\mathrm{CuCl}$ in the same way as described for its initial preparation. The recharged catalyst obtained (60 $\mathrm{mg}$ ) was used in another run of the RCM of $\mathbf{1 1}$ under otherwise identical condition. After fluorous extraction of the reaction mixture, the crude reaction product was analyzed $500 \mathrm{MHz}{ }^{1} \mathrm{H}$ NMR which indicated complete conversion of the diene $\mathbf{1 1}$ and clean and quantitative formation of the cyclized product $\mathbf{1 4 .}$

\section{RCM of Diene 15 (Table 2, catalyst batch A)}

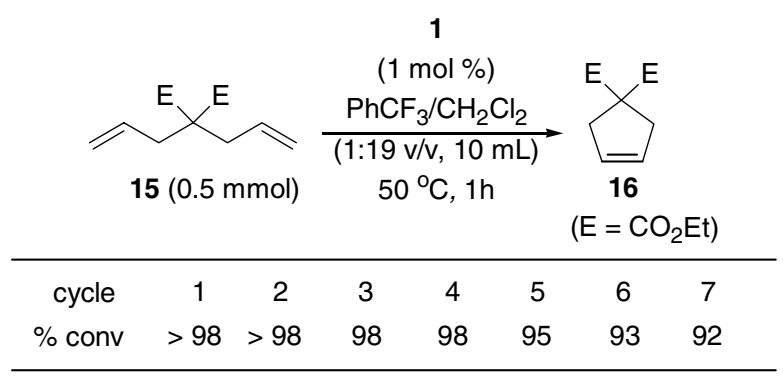

Catalyst 1, prepared according to the general procedure from $28 \mathrm{mg}(0.0050 \mathrm{mmol})$ of $\mathbf{8}, 5.0 \mathrm{mg}(0.0075 \mathrm{mmol})$ of 3 and $0.5 \mathrm{mg}(0.005 \mathrm{mmol})$ of $\mathrm{CuCl}$, was placed in a $50 \mathrm{~mL}$ flask equipped with a reflux condenser. After the flask was degassed three times by evacuation and then filling with $\mathrm{Ar}, \mathrm{PhCF}_{3}(0.5 \mathrm{~mL})$ was added to dissolve the catalyst followed by diethyl diallylmalonate $15(120 \mathrm{mg}, 0.50 \mathrm{mmol})$ dissolved in $\mathrm{CH}_{2} \mathrm{Cl}_{2}(9.5 \mathrm{~mL})$. After heating to reflux (bath temperature $45-50^{\circ} \mathrm{C}$ ) for $1 \mathrm{~h}$, the reaction mixture was cooled to $\mathrm{rt}$ and concentrated to dryness under vacuum. After fluorous extraction of the reaction mixture following the general procedure, the crude reaction product was analyzed by $500 \mathrm{M} \mathrm{Hz}{ }^{1} \mathrm{H}$ NMR which indicated complete conversion of $\mathbf{1 5}$ and clean and quantitative formation of the known cyclized product 16. ${ }^{8} 16:{ }^{1} \mathrm{H} \mathrm{NMR}\left(\mathrm{CDCl}_{3}, 500 \mathrm{MHz}\right): \delta 5.62(\mathrm{~s}$, $2 \mathrm{H}), 4.21(\mathrm{q}, 4 \mathrm{H}, J=7.2 \mathrm{~Hz}), 3.02(\mathrm{~s}, 4 \mathrm{H}), 1.26(\mathrm{t}, 6 \mathrm{H}, J=7.1 \mathrm{~Hz})$.

This reaction was repeated 6 more times, each using the catalyst recycled from the previous run. The results were listed in Table 2 of the text.

\section{RCM of Dienes 17-21 (Table 2, catalyst batch B)}

\section{Cycle 1:}




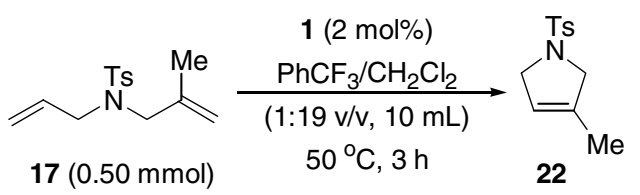

Catalyst 1, prepared according to the general procedure from $56 \mathrm{mg}(0.010 \mathrm{mmol})$ of $\mathbf{8}, 10 \mathrm{mg}(0.015 \mathrm{mmol})$ of 3 and $1.0 \mathrm{mg}(0.010 \mathrm{mmol})$ of $\mathrm{CuCl}$, was placed in a $50 \mathrm{~mL}$ flask equipped with a reflux condenser and the flask was degassed three times by evacuation and then filling with $\mathrm{Ar}$. $\mathrm{PhCF}_{3}(0.5 \mathrm{~mL})$ was then added to dissolve the catalyst followed by diene $17(133 \mathrm{mg}, 0.50 \mathrm{mmol})$ in $\mathrm{CH}_{2} \mathrm{Cl}_{2}(9.5 \mathrm{~mL})$. After heating to reflux (bath temperature $45-50^{\circ} \mathrm{C}$ ) for $3 \mathrm{~h}$, the reaction mixture was cooled to rt and concentrated to dryness under vacuum. After fluorous extraction of the reaction mixture, the crude reaction product was analyzed by $500 \mathrm{MHz}{ }^{1} \mathrm{H} \mathrm{NMR}$ which indicated complete conversion of the diene $\mathbf{1 7}$ and the clean formation of cyclized product 22. Purification by flash column chromatography (hexanes/EtOAc, 8:1 v/v) gave the known compound $\mathbf{2 2}^{9}(111$ mg, $94 \%)$ as a white solid. 22: ${ }^{1} \mathrm{H}$ NMR $\left(\mathrm{CDCl}_{3}, 500 \mathrm{MHz}\right): \delta 7.72(\mathrm{~d}, 2 \mathrm{H}, J=8.2 \mathrm{~Hz}), 7.32(\mathrm{~d}, 2 \mathrm{H}, J=8.1$ Hz), 5.25 (m, 1 H), 4.06-4.08 (m, 2 H), 3.97 (bs, 2 H), 2.43 (s, 3 H), 1.66 (s, 3 H).

\section{Cycle 2:}

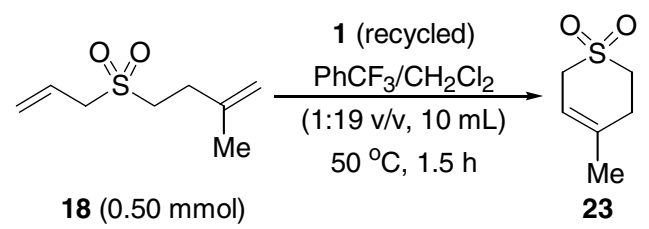

The catalyst recycled from the RCM of $\mathbf{1 7}$ (cycle 1) was used in the RCM of $\mathbf{1 8}(86 \mathrm{mg}, 0.50 \mathrm{mmol})$ under identical conditions to these of $\mathbf{1 7}$ except that the reaction mixture was heated to reflux (bath temperature 45 $50^{\circ} \mathrm{C}$ ) for $1.5 \mathrm{~h}$. The reaction mixture was cooled to $\mathrm{rt}$ and concentrated to dryness under vacuum. After fluorous extraction of the reaction mixture, $500 \mathrm{MHz}{ }^{1} \mathrm{H}$ NMR analysis of the crude reaction product indicated complete conversion of the diene $\mathbf{1 8}$ and clean formation of 23. Purification by flash column chromatography (hexanes $/ \mathrm{CH}_{2} \mathrm{Cl}_{2}, 1: 3 \mathrm{v} / \mathrm{v}$ ) gave the known cyclic sulfone $\mathbf{2 3}^{10}(66 \mathrm{mg}, 90 \%)$ as a white solid. 23: ${ }^{1} \mathrm{H}$ NMR $\left(\mathrm{CDCl}_{3}, 500 \mathrm{MHz}\right): \delta 5.33-5.34(\mathrm{~m}, 1 \mathrm{H}), 3.55(\mathrm{bs}, 2 \mathrm{H}), 3.05(\mathrm{t}, 2 \mathrm{H}, J=6.5 \mathrm{~Hz}), 2.65(\mathrm{t}, 2 \mathrm{H}, J=5.5 \mathrm{~Hz}), 1.77$ $(\mathrm{s}, 3 \mathrm{H})$.

\section{Cycle 3:}

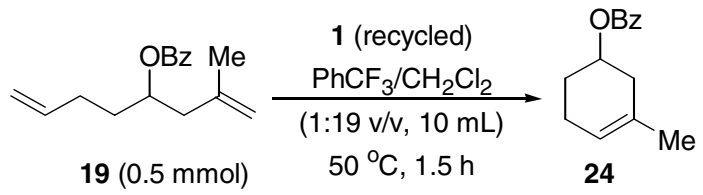

The catalyst recycled from the RCM of $\mathbf{1 8}$ (cycle 2) was used in the RCM of $\mathbf{1 9}$ (124 $\mathrm{mg}, 0.50 \mathrm{mmol}$ ) under identical conditions to these of $\mathbf{1 8}$. The reaction mixture was cooled to $\mathrm{rt}$ and concentrated to dryness under vacuum. After fluorous extraction of the reaction mixture, $500 \mathrm{MHz}{ }^{1} \mathrm{H}$ NMR analysis of the crude reaction product indicated complete conversion of the diene 19 and clean formation of 24 . Purification by flash column chromatography (hexanes/EtOAc, 95:5 v/v) gave 24 (102 mg, 94\%) as colorless oil.

24: ${ }^{1} \mathrm{H}$ NMR $\left(\mathrm{CDCl}_{3}, 500 \mathrm{MHz}\right): \delta 8.05(\mathrm{~d}, 2 \mathrm{H}, J=7.4 \mathrm{~Hz}), 7.56(\mathrm{t}, 1 \mathrm{H}, J$ $=7.4 \mathrm{~Hz}), 7.44(\mathrm{t}, 2 \mathrm{H}, J=7.8 \mathrm{~Hz}), 5.45(\mathrm{bs}, 1 \mathrm{H}), 5.28-5.32(\mathrm{~m}, 1 \mathrm{H})$, 2.14-2.42 (m, $4 \mathrm{H}), 1.79-1.98(\mathrm{~m}, 2 \mathrm{H}), 1.70(\mathrm{~s}, 3 \mathrm{H}) .{ }^{13} \mathrm{C} \mathrm{NMR}\left(\mathrm{CDCl}_{3}\right.$, $125 \mathrm{MHz}): \delta 166.2,132.7,131.0,130.9,129.6,128.3,120.6,70.8,35.5$, 27.1, 23.4, 22.9. Anal. Calcd for $\mathrm{C}_{14} \mathrm{H}_{16} \mathrm{O}_{2}: \mathrm{C}, 77.75 ; \mathrm{H}, 7.46$. Found: $\mathrm{C}$, $77.79 ; \mathrm{H}, 7.62$.

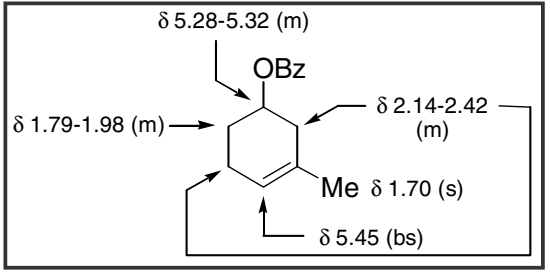

\section{Cycle 4:}




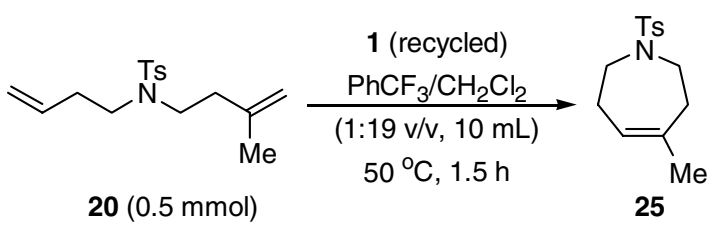

The catalyst recycled from the RCM of $\mathbf{1 9}$ (cycle 3) was used in the RCM of $\mathbf{2 0}$ (147 $\mathrm{mg}, 0.50 \mathrm{mmol}$ ) under identical conditions to these of 19. The reaction mixture was cooled to $\mathrm{rt}$ and concentrated to dryness under vacuum. After fluorous extraction of the reaction mixture, $500 \mathrm{MHz}{ }^{1} \mathrm{H}$ NMR analysis of the crude reaction product indicated complete conversion of the diene $\mathbf{2 0}$ and clean formation of $\mathbf{2 5}$. Purification by flash column chromatography (hexanes/EtOAc, 6:1 v/v) gave $25(128 \mathrm{mg}, 96 \%)$ as a slightly yellow oil.

25: ${ }^{1} \mathrm{H} \mathrm{NMR}\left(\mathrm{CDCl}_{3}, 500 \mathrm{MHz}\right): \delta 7.66(\mathrm{~d}, 2 \mathrm{H}, J=8.0 \mathrm{~Hz}), 7.30(\mathrm{~d}, 2 \mathrm{H}, J=8.0 \mathrm{~Hz})$, $5.48(\mathrm{t}, 1 \mathrm{H}, J=5.7 \mathrm{~Hz}), 3.25-3.29(\mathrm{~m}, 4 \mathrm{H}), 2.43(\mathrm{~s}, 3 \mathrm{H}), 2.22-2.27(\mathrm{~m}, 4 \mathrm{H}), 1.68(\mathrm{~s}, 3$ $\mathrm{H}) .{ }^{13} \mathrm{C} \mathrm{NMR}\left(\mathrm{CDCl}_{3}, 125 \mathrm{MHz}\right): \delta 143.1,138.8,135.5,129.6,127.1,123.9,48.2,46.8$, 34.7, 28.3, 26.0, 21.5. Anal. Calcd for $\mathrm{C}_{14} \mathrm{H}_{19} \mathrm{NO}_{2} \mathrm{~S}$ : C, 63.36; H, 7.22; N, 5.28. Found: C, 63.19; H, 7.54; N, 5.26.

\section{Cycle 5:}
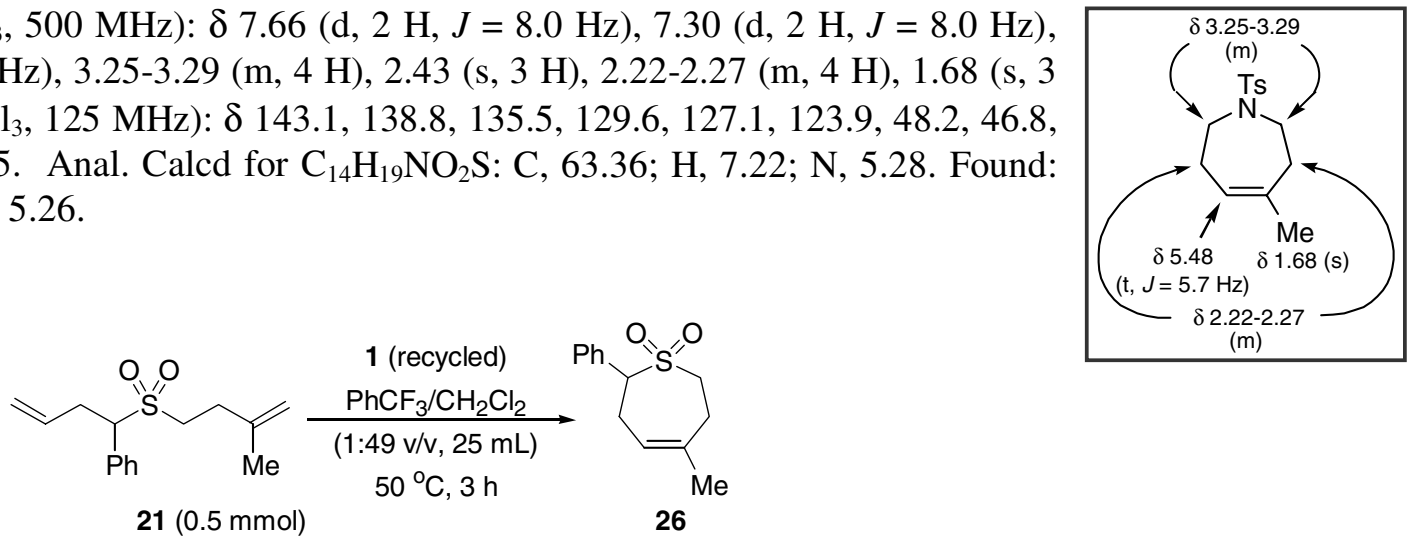

The catalyst recycled from the RCM of $\mathbf{2 0}$ (cycle 4) was used in the RCM of $\mathbf{2 1}$ (132 $\mathrm{mg}, 0.50 \mathrm{mmol}$ ) in the mixed solvent system $\mathrm{PhCF}_{3} / \mathrm{CH}_{2} \mathrm{Cl}_{2}(25 \mathrm{~mL}, 1: 49 \mathrm{v} / \mathrm{v})$. The reaction mixture was heated to reflux (bath temperature $45-50^{\circ} \mathrm{C}$ ) for $3 \mathrm{~h}$ and then cooled to $\mathrm{rt}$ and concentrated to dryness under vacuum. After fluorous extraction of the reaction mixture, $500 \mathrm{MHz}{ }^{1} \mathrm{H}$ NMR analysis of the crude reaction product indicated complete conversion of the diene 21 and clean formation of 26. Purification by flash column chromatography (hexanes $/ \mathrm{CH}_{2} \mathrm{Cl}_{2}, 1: 2 \mathrm{v} / \mathrm{v}$ ) gave $\mathbf{2 6}(107 \mathrm{mg}, 91 \%)$ as a white solid.

26: ${ }^{1} \mathrm{HNMR}\left(\mathrm{CDCl}_{3}, 500 \mathrm{MHz}\right): \delta 7.38(\mathrm{~m}, 5 \mathrm{H}), 5.77$ $(\mathrm{m}, 1 \mathrm{H}), 3.89(\mathrm{~d}, 1 \mathrm{H}, J=11.2 \mathrm{~Hz}), 3.24(\mathrm{dd}, 1 \mathrm{H}, J=$ 8.0, $14.3 \mathrm{~Hz}), 3.13(\mathrm{~m}, 1 \mathrm{H}), 2.95(\mathrm{~m}, 1 \mathrm{~Hz}), 2.84(\mathrm{~m}, 1$ $\mathrm{H}), 2.50(\mathrm{dd}, 1 \mathrm{H}, J=8.8,15.7 \mathrm{~Hz}), 2.31(\mathrm{dd}, 1 \mathrm{H}, J=$ 7.9, $15.7 \mathrm{~Hz}), 1.87(\mathrm{~s}, 3 \mathrm{H}) .{ }^{13} \mathrm{C} \mathrm{NMR}\left(\mathrm{CDCl}_{3}, 125\right.$ $\mathrm{MHz}): \delta 140.7,131.9,130.2,129.1,128.9,124.2,68.9$,

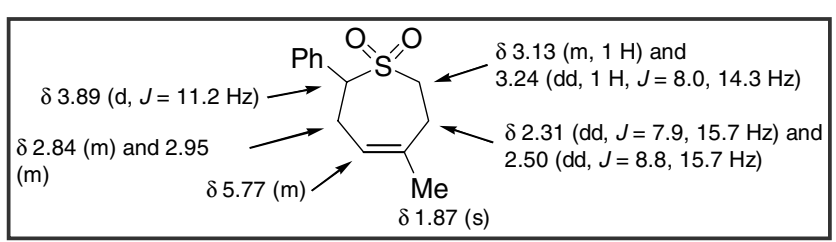
53.4, 29.2, 26.9, 25.5. Anal. Calcd for $\mathrm{C}_{13} \mathrm{H}_{16} \mathrm{O}_{2} \mathrm{~S}: \mathrm{C}, 66.07 ; \mathrm{H}, 6.82$. Found: C, 65.87; H, 6.72.

\section{RCM of Diene 27, Cross Metathesis of 28 and RCM of the Enyne 29 (Table 2, catalyst batch C)}

\section{Cycle 1:}

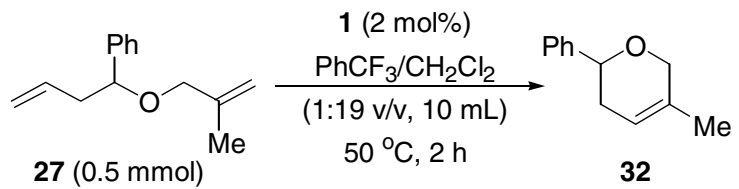

Catalyst 1, prepared according the general procedure from $56 \mathrm{mg}(0.010 \mathrm{mmol})$ of $\mathbf{8}, 10 \mathrm{mg}(0.015 \mathrm{mmol})$ of $\mathbf{3}$ and $1.0 \mathrm{mg}(0.010 \mathrm{mmol})$ of $\mathrm{CuCl}$, was placed in a $50 \mathrm{~mL}$ flask equipped with a reflux condenser and the flask was degassed three times by evacuation and then filling with $\mathrm{Ar} . \mathrm{PhCF}_{3}(0.5 \mathrm{~mL})$ was then added to dissolve the catalyst followed by diene 27 (101 mg, $0.5 \mathrm{mmol}$ ) in $\mathrm{CH}_{2} \mathrm{Cl}_{2}(9.5 \mathrm{~mL})$. After heating to reflux (bath temperature $45-50^{\circ} \mathrm{C}$ ) for $2 \mathrm{~h}$, the reaction mixture was cooled to $\mathrm{rt}$ and concentrated under vacuum. After fluorous extraction of the reaction mixture, $500 \mathrm{MHz}{ }^{1} \mathrm{H}$ NMR analysis of the crude reaction product indicated complete conversion of diene $\mathbf{2 7}$ and clean formation of the cyclized product 32. Purification by flash column chromatography (hexanes $/ \mathrm{CH}_{2} \mathrm{Cl}_{2}, 4: 1 \mathrm{v} / \mathrm{v}$ ) gave the known cyclic ether $\mathbf{3 2}^{11}(83 \mathrm{mg}, 95 \%$ ) as a colorless oil. 32: 
${ }^{1} \mathrm{H}$ NMR $\left(\mathrm{CDCl}_{3}, 500 \mathrm{MHz}\right): \delta$ 7.27-7.40 (m, $\left.5 \mathrm{H}\right), 5.61(\mathrm{~m}, 1 \mathrm{H}), 4.51(\mathrm{dd}, 1 \mathrm{H}, J=3.6,10.2 \mathrm{~Hz}), 4.27(\mathrm{~d}, 2 \mathrm{H}$, $J=16.1 \mathrm{~Hz}), 4.18(\mathrm{~d}, 1 \mathrm{H}, J=16.1 \mathrm{~Hz}), 2.22-2.36(\mathrm{~m}, 2 \mathrm{H}), 1.68(\mathrm{~s}, 3 \mathrm{H})$.

Cycle 2:

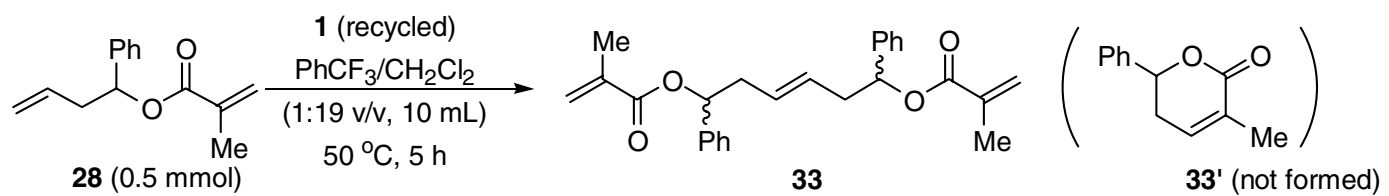

The catalyst recycled from the RCM of 27 (cycle 1) was used in the metathesis reaction of 28 (109 $\mathrm{mg}, 0.50$ mmol) under identical conditions to these of 27 except that the reaction mixture was heated to reflux (bath temperature $45-50^{\circ} \mathrm{C}$ ) for $5 \mathrm{~h}$. After fluorous extraction of the reaction mixture, $500 \mathrm{MHz}{ }^{1} \mathrm{H}$ NMR analysis of the reaction crude revealed a ratio of 89:11 between the cross metathesis product $\mathbf{3 3}$ and diene $\mathbf{2 8}$ with no indication for the formation of the cyclized product $\mathbf{3 3}^{\prime}$. Purification by flash column chromatography (hexanes $/ \mathrm{CH}_{2} \mathrm{Cl}_{2}, 2: 1 \mathrm{v} / \mathrm{v}$ then hexanes/EtOAc, 8:1 v/v) gave the trans-olefin $\mathbf{3 3}(80 \mathrm{mg}, 85 \%$ ) as a mixture of inseparable diastereomers.

33: ${ }^{1} \mathrm{H}$ NMR $\left(\mathrm{CDCl}_{3}, 500 \mathrm{MHz}\right): \delta 7.27-7.35(\mathrm{~m}, 5 \mathrm{H})$, 6.14(s, $1 \mathrm{H}$ ), 5.74 (minor isomer, $\mathrm{t}, J=6.7 \mathrm{~Hz}$ ) and 5.73 (major isomer, t, $J=7.2 \mathrm{~Hz}$ ) (total $1 \mathrm{H}$ ), 5.57 (bs, $1 \mathrm{H}$ ), 5.41 (minor isomer, $\mathrm{m}$ ) and 5.39 (major isomer, $\mathrm{dt}, J=1.6,3.7 \mathrm{~Hz})($ total $1 \mathrm{H}), 2.58-2.64(\mathrm{~m}, 1 \mathrm{H})$, 2.49-2.54 (m, $1 \mathrm{H}), 1.94(\mathrm{~s}, 3 \mathrm{H}) .{ }^{13} \mathrm{C} \mathrm{NMR}\left(\mathrm{CDCl}_{3}\right.$, $125 \mathrm{MHz}): \delta 166.5,140.2,136.5,128.4,127.9,127.0$, $126.4,125.5,75.7$ (major isomer) and 75.5 (minor isomer), 39.7 (major isomer) and 34.5 (minor isomer), 18.2. Anal. Calcd for $\mathrm{C}_{26} \mathrm{H}_{28} \mathrm{O}_{4}$ : C, 77.20; $\mathrm{H}, 6.98$.

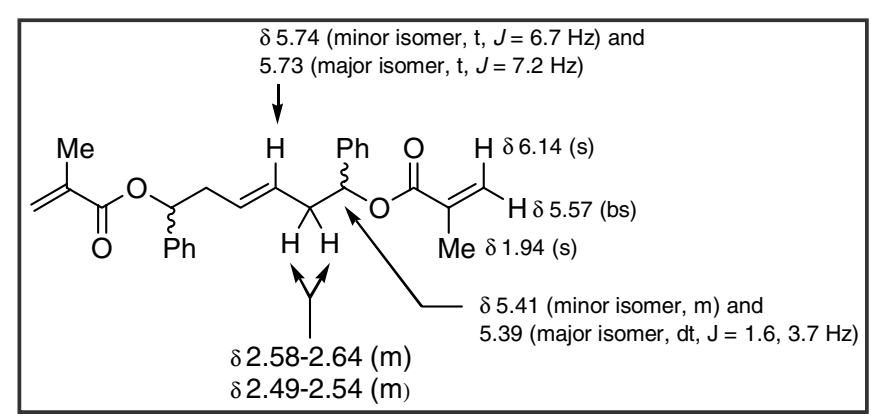
Found: C, 77.03; H, 7.31.

\section{Cycle 3:}

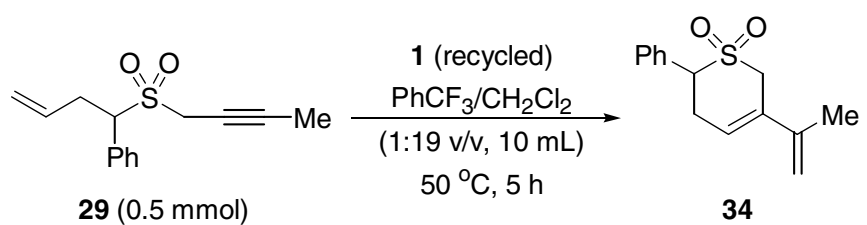

The catalyst recycled from the reaction of $\mathbf{2 8}$ (cycle 2) was used the RCM of the enyne $\mathbf{2 9}^{12}$ (124 $\mathrm{mg}, 0.50$ mmol) under identical conditions to these of 28. After fluorous extraction of the reaction mixture, ${ }^{1} \mathrm{H}$ NMR analysis of the reaction crude revealed a ratio of 80:20 between the cyclized product $\mathbf{3 4}$ and enyne 29. Purification by flash column chromatography (hexanes $/ \mathrm{CH}_{2} \mathrm{Cl}_{2}, 1: 1 \mathrm{v} / \mathrm{v}$ then $\mathrm{CH}_{2} \mathrm{Cl}_{2}$ ) gave the known cyclic sulfone $\mathbf{3 4}^{12}(92 \mathrm{mg}, 74 \%)$ as a white solid. 34: ${ }^{1} \mathrm{H}$ NMR $\left(\mathrm{CDCl}_{3}, 500 \mathrm{MHz}\right)$ : $87.48-7.50(\mathrm{~m}, 2 \mathrm{H}), 7.41-7.43$ $(\mathrm{m}, 3 \mathrm{H}), 6.11(\mathrm{bs}, 1 \mathrm{H}), 5.04(\mathrm{~s}, 1 \mathrm{H}), 4.91(\mathrm{~s}, 1 \mathrm{H}), 4.21(\mathrm{dd}, 1 \mathrm{H}, J=4.9,10.6 \mathrm{~Hz}), 3.97(\mathrm{~d}, 1 \mathrm{H}, J=17.1 \mathrm{~Hz})$, $3.88(\mathrm{~d}, 1 \mathrm{H}, J=17.0 \mathrm{~Hz}), 3.34(\mathrm{dd}, 1 \mathrm{H}, J=10.7,18.7 \mathrm{~Hz}), 3.05(\mathrm{dt}, 1 \mathrm{H}, J=18.9,5.3 \mathrm{~Hz}), 1.99$ (s, $3 \mathrm{H})$.

\section{RCM of Diene 30 (Table 2, catalyst batch D)}

\section{Cycle 1:}

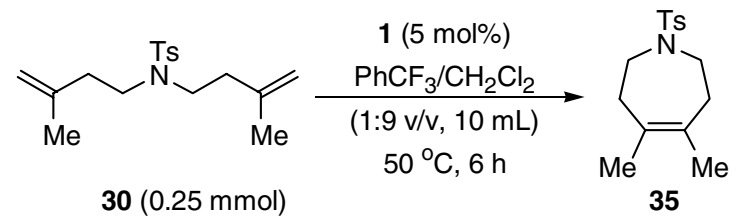

The catalyst 1, prepared according to the general procedure from $70 \mathrm{mg}(0.013 \mathrm{mmol})$ of $\mathbf{8}, 16 \mathrm{mg}(0.019 \mathrm{mmol})$ of 3 and $1.3 \mathrm{mg}(0.013 \mathrm{mmol})$ of $\mathrm{CuCl}$, was placed in a $50 \mathrm{~mL}$ flask equipped with a reflux condenser and the 
flask was degassed three times by evacuation and then filling with $\mathrm{Ar}$. $\mathrm{PhCF}_{3}(0.5 \mathrm{~mL})$ was then added to dissolve the catalyst followed by diene $30(77 \mathrm{mg}, 0.25 \mathrm{mmol})$ in $\mathrm{CH}_{2} \mathrm{Cl}_{2}(4.5 \mathrm{~mL})$. After heating to reflux (bath temperature $45-50^{\circ} \mathrm{C}$ ) for $6 \mathrm{~h}$, the reaction mixture was cooled to $\mathrm{rt}$ and concentrated under vacuum. After fluorous extraction of the reaction mixture, ${ }^{1} \mathrm{H}$ NMR analysis of the reaction crude revealed a ratio of 43:57 between the cyclized product $\mathbf{3 5}$ and diene 30. Purification by flash column chromatography (hexanes/EtOAc, $12: 1 \mathrm{v} / \mathrm{v})$ gave $35(27 \mathrm{mg}, 39 \%)$ as a colorless oil.

35: ${ }^{1} \mathrm{H}$ NMR $\left(\mathrm{CDCl}_{3}, 500 \mathrm{MHz}\right): \delta 7.64(\mathrm{~d}, 2 \mathrm{H}, J=8.2 \mathrm{~Hz}), 7.29(\mathrm{~d}, 2 \mathrm{H}, J=8.1 \mathrm{~Hz}), 3.18(\mathrm{t}$, $4 \mathrm{H}, J=5.2 \mathrm{~Hz}), 2.42(\mathrm{~s}, 3 \mathrm{H}), 2.26(\mathrm{t}, 4 \mathrm{H}, J=5.2 \mathrm{~Hz}), 1.61(\mathrm{~s}, 6 \mathrm{H}) \cdot{ }^{13} \mathrm{C} \mathrm{NMR}\left(\mathrm{CDCl}_{3}, 125\right.$ $\mathrm{MHz}): \delta 143.1,135.3,130.2,129.6,127.3,46.8,35.4,21.5,21.3$. Anal. Calcd for $\mathrm{C}_{15} \mathrm{H}_{21} \mathrm{NO}_{2} \mathrm{~S}: \mathrm{C}, 64.48 ; \mathrm{H}, 7.58 ; \mathrm{N}, 5.01$. Found: C, 64.37; H, 7.68; N, 4.89.

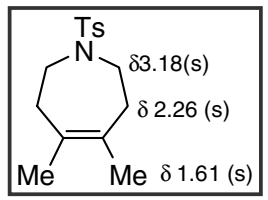

\section{Cycle 2:}

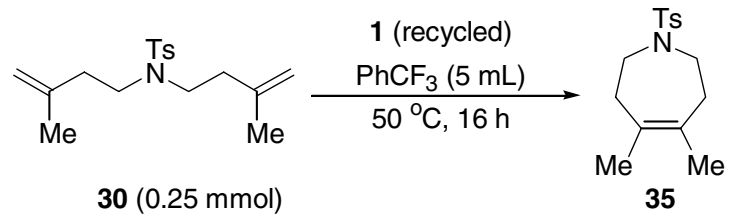

A second run of the $\mathrm{RCM}$ of $\mathbf{3 0}(77 \mathrm{mg}, 0.25 \mathrm{mmol})$ in $\mathrm{PhCF}_{3}(5 \mathrm{~mL})$ was performed using the catalyst recycled from the first run. After heating to reflux (bath temperature $45-50^{\circ} \mathrm{C}$ ) for $16 \mathrm{~h}$, the reaction mixture was cooled to rt and concentrated to dryness. After fluorous extraction of the reaction mixture, ${ }^{1} \mathrm{H}$ NMR analysis of the reaction crude revealed a ratio of $94: 6$ between the cyclized product $\mathbf{3 5}$ and the diene $\mathbf{3 0}$. Purification by flash column chromatography (hexanes/EtOAc, 12:1 v/v) gave 35 (65 mg, 93\%) as a colorless oil.

\section{RCM of Dienes 31 and 20 (Table 2, catalyst batch E)}

\section{Cycle 1:}

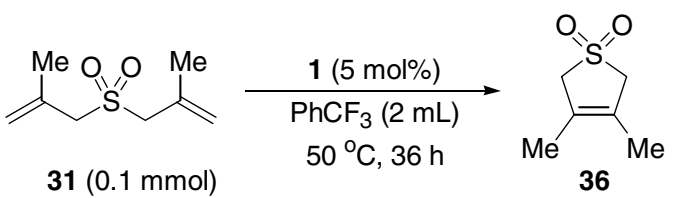

Catalyst 1, prepared according to the general procedure from $28 \mathrm{mg}(0.0050 \mathrm{mmol})$ of $\mathbf{8}, 5.0 \mathrm{mg}(0.0075 \mathrm{mmol})$ of 3 and $0.5 \mathrm{mg}(0.005 \mathrm{mmol})$ of $\mathrm{CuCl}$ in $\mathrm{PhCF}_{3}(0.5 \mathrm{~mL})$, was placed in a $50 \mathrm{~mL}$ flask equipped with a reflux condenser and the flask was degassed three times by evacuation and then filling with Ar. A solution of diene $\mathbf{3 1}$ $(18 \mathrm{mg}, 0.10 \mathrm{mmol})$ in $\mathrm{PhCF}_{3}(2 \mathrm{~mL})$ was added. After heating to $45-50{ }^{\circ} \mathrm{C}$ (bath temperature) for $36 \mathrm{~h}$, the reaction mixture was cooled to $\mathrm{rt}$ and concentrated under vacuum. After fluorous extraction of the reaction mixture, ${ }^{1} \mathrm{H}$ NMR analysis of the reaction crude revealed a ratio of 51:49 between the cyclized product $\mathbf{3 6}$ and diene 31. Purification by flash column chromatography (hexanes: $\mathrm{CH}_{2} \mathrm{Cl}_{2}, 1: 2 \mathrm{v} / \mathrm{v}$ ) gave the known cyclic sulfone $\mathbf{3 6}^{12}(7 \mathrm{mg}, 50 \%)$ as a white foam. 36: ${ }^{1} \mathrm{H} \mathrm{NMR}\left(\mathrm{CDCl}_{3}, 500 \mathrm{MHz}\right): \delta 3.74(\mathrm{~s}, 4 \mathrm{H}), 1.79(\mathrm{~s}, 6 \mathrm{H})$.

\section{Cycle 2:}

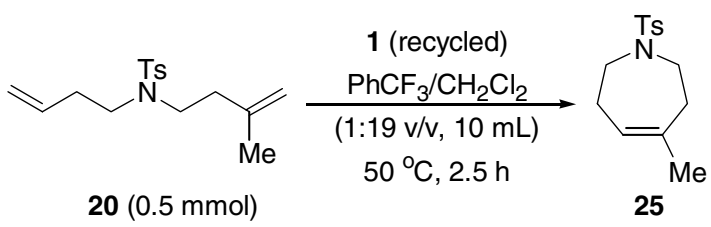

The catalyst recycled from the RCM of 31was used for the RCM of diene 20 (74 $\mathrm{mg}, 0.25 \mathrm{mmol}$ ) in $\mathrm{PhCF}_{3} / \mathrm{CH}_{2} \mathrm{Cl}_{2}(1: 9 \mathrm{v} / \mathrm{v}, 5 \mathrm{~mL})$. After heating to reflux (bath temperature $45-50^{\circ} \mathrm{C}$ ) for $2.5 \mathrm{~h}$, the reaction mixture was cooled to $\mathrm{rt}$ and concentrated to dryness. After fluorous extraction of the reaction mixture, $500 \mathrm{MHz}{ }^{1} \mathrm{H}$ NMR analysis of the crude reaction product revealed a ratio of 96:4 between the cyclized product $\mathbf{2 5}$ and diene 20. Purification by flash column chromatography (hexanes/EtOAc, 6:1 v/v) gave pure 25 (64 mg, 96\%). 


\section{References}

1 Yao, Q. Angew. Chem. Int. Ed. 2000, 39, 3896.

2 Scholl, M.; Ding, S.; Lee, C. W.; Grubbs, R. H. Org. Lett. 1999, 1, 953.

3 Garber, S. B.; Kingsbury, J. S.; Gray, B. L.; Hoveyda, A. H. J. Am. Chem. Soc. 2000, 122, 8168.

4 Gessler, S.; Randl, S.; Blechert, S. Tetrahedron Lett. 2000, 41, 9973

5 Varray, S.; Lazaro, R.; Martinez, J.; Lamaty, F. Organometallics 2003, 22, 2426.

6 Visser, M. S.; Heron, N. M.; Didiuk, M. T.; Sagal, J. F.; Hoveyda, A. H. J. Am. Chem. Soc. 1996, 118, 4291.

7 Tamaru, Y.; Hojo, M.; Yoshida, Z. J. Org. Chem. 1988, 53, 5731.

8 Nugent, W. A.; Feldman, J.; and Calabrese, J. C. J. Am. Chem. Soc. 1995, 117, 8992.

9 Knight, J. G.; Muldowney, M. P. Synlett 1995, 949.

10 Polakova, J.; Palecek, M.; Prochazka, M. Coll. Czech. Chem. Comm. 1979, 4, 3705.

11 Fu, G. C.; Grubbs, R. H. J. Am. Chem. Soc. 1992, 114, 5426.

12 Yao, Q. Org. Lett. 2002, 4, 428. 